\title{
Effects of lightning $\mathrm{NO}_{\mathrm{x}}$ production during the 21 July European Lightning Nitrogen Oxides Project storm studied with a three-dimensional cloud-scale chemical transport model
}

\author{
Lesley E. Ott, ${ }^{1}$ Kenneth E. Pickering, ${ }^{1,2}$ Georgiy L. Stenchikov, ${ }^{3}$ Heidi Huntrieser, ${ }^{4}$ and \\ Ulrich Schumann ${ }^{4}$
}

Received 3 April 2006; revised 17 September 2006; accepted 2 November 2006; published 14 March 2007.

[1] The 21 July 1998 thunderstorm observed during the European Lightning Nitrogen Oxides Project (EULINOX) project was simulated using the three-dimensional Goddard Cumulus Ensemble (GCE) model. The simulation successfully reproduced a number of observed storm features including the splitting of the original cell into a southern cell which developed supercell characteristics and a northern cell which became multicellular. Output from the GCE simulation was used to drive an offline cloud-scale chemical transport model which calculates tracer transport and includes a parameterization of lightning $\mathrm{NO}_{\mathrm{x}}$ production which uses observed flash rates as input. Estimates of lightning $\mathrm{NO}_{\mathrm{x}}$ production were deduced by assuming various values of production per intracloud and production per cloud-to-ground flash and comparing the results with in-cloud aircraft observations. The assumption that both types of flashes produce 360 moles of NO per flash on average compared most favorably with column mass and probability distribution functions calculated from observations. This assumed production per flash corresponds to a global annual lightning $\mathrm{NO}_{\mathrm{x}}$ source of $7 \mathrm{Tg} \mathrm{N} \mathrm{yr}^{-1}$. Chemical reactions were included in the model to evaluate the impact of lightning $\mathrm{NO}_{\mathrm{x}}$ on ozone. During the storm, the inclusion of lightning $\mathrm{NO}_{\mathrm{x}}$ in the model results in a small loss of ozone (on average less than $4 \mathrm{ppbv}$ ) at all model levels. Simulations of the chemical environment in the 24 hours following the storm show on average a small increase in the net production of ozone at most levels resulting from lightning $\mathrm{NO}_{\mathrm{x}}$, maximizing at approximately $5 \mathrm{ppbv}$ day $^{-1}$ at $5.5 \mathrm{~km}$. Between 8 and $10.5 \mathrm{~km}$, lightning $\mathrm{NO}_{\mathrm{x}}$ causes decreased net ozone production.

Citation: Ott, L. E., K. E. Pickering, G. L. Stenchikov, H. Huntrieser, and U. Schumann (2007), Effects of lightning $\mathrm{NO}_{\mathrm{x}}$ production during the 21 July European Lightning Nitrogen Oxides Project storm studied with a three-dimensional cloud-scale chemical transport model, J. Geophys. Res., 112, D05307, doi:10.1029/2006JD007365.

\section{Introduction}

[2] The nitrogen oxides $\mathrm{NO}$ and $\mathrm{NO}_{2}\left(\mathrm{NO}_{\mathrm{x}}\right)$ are important trace gases in the troposphere, the presence of which in sufficient quantities may result in the photochemical production of ozone. Fossil fuel combustion, biomass burning, microbial activity in soils, and lightning are considered the four major sources of tropospheric $\mathrm{NO}_{\mathrm{x}}$ [Bradshaw et al., 2000]. Though lightning produces much less $\mathrm{NO}_{x}$ than the anthropogenic sources, it is a particularly significant source because lightning produces $\mathrm{NO}_{\mathrm{x}}$ mainly in the middle and

\footnotetext{
${ }^{1}$ Department of Atmospheric and Oceanic Science, University of Maryland, College Park, Maryland, USA.

${ }^{2}$ Also at NASA Goddard Space Flight Center, Greenbelt, Maryland, USA.

${ }^{3}$ Department of Environmental Sciences, Rutgers University, New Brunswick, New Jersey, USA.

${ }^{4}$ Institut für Physik der Atmosphäre, Deutsches Zentrum für Luft- und Raumfahrt, Oberpfaffenhofen, Germany.

Copyright 2007 by the American Geophysical Union. 0148-0227/07/2006JD007365\$09.00
}

upper troposphere where it is longer-lived, typically at more dilute concentrations, and, consequently, more efficient at producing ozone than in the boundary layer where the majority of $\mathrm{NO}_{\mathrm{x}}$ is emitted.

[3] The strength of the global $\mathrm{NO}_{\mathrm{x}}$ source from lightning remains uncertain, with values in the literature ranging over an order of magnitude $\left(3.2-26 \mathrm{Tg} \mathrm{N} \mathrm{yr}^{-1}\right.$ ) [Bradshaw et al., 2000], although most recent estimates are confined to the lower half of this range as summarized by Zhang et al. [2003]. Contributing to the widely varying global estimates are uncertainties in both the total number of flashes and amount of $\mathrm{NO}_{\mathrm{x}}$ produced per flash or per meter of flash length. There is also debate regarding the relative $\mathrm{NO}$ production by intracloud (IC) and cloud-to-ground (CG) flashes [e.g., Ridley et al., 2005]. On the basis of previous studies which suggested that IC flashes were less energetic than CG flashes [e.g., Holmes et al., 1971], many studies of lightning $\mathrm{NO}_{\mathrm{x}}$ production have assumed that production by an IC flash $\left(\mathrm{P}_{\mathrm{IC}}\right)$ is less than production by a CG flash $\left(\mathrm{P}_{\mathrm{CG}}\right)$. Price et al. [1997] assumed that production by an IC flash $\left(\mathrm{P}_{\mathrm{IC}}\right)$ was one tenth of production by a $\mathrm{CG}$ flash $\left(\mathrm{P}_{\mathrm{CG}}\right)$ 
Table 1. Estimates of NO Production per Flash

\begin{tabular}{lclc}
\hline \multicolumn{1}{c}{ Author(s) } & Field Project & Method & $\begin{array}{c}\text { NO Production, } \\
\text { moles NO per flash }\end{array}$ \\
\hline DeCaria et al. [2000] & STERAO & 2-D cloud model, aircraft observations & $230-460$ \\
DeCaria et al. [2005] & STERAO & 3-D Cloud model, aircraft observations & $345-460$ \\
Fehr et al. $[2004]$ & EULINOX & 3-D cloud model, aircraft observations & $330-462$ \\
Huntrieser et al. $[1998]$ & LINOX & Aircraft observations & $66-498$ \\
Skamarock et al. $[2003]$ & STERAO & 3-D cloud model, aircraft observations, & 43 \\
Théry et al. [2000] & & lightning observations & 500 \\
\hline
\end{tabular}

in calculating global lightning $\mathrm{NO}_{\mathrm{x}}$ production. Gallardo and Cooray [1996] suggested that IC flashes may dissipate nearly as much energy as CG flashes and therefore $\mathrm{P}_{\text {IC }}$ may be on the order of $\mathrm{P}_{\mathrm{CG}}$. Supporting the Gallardo and Cooray [1996] hypothesis, a 2-D cloud-scale modeling study by DeCaria et al. [2000] suggested that the $\mathrm{P}_{\mathrm{IC}} / \mathrm{P}_{\mathrm{CG}}$ ratio is likely between 0.5 and 1.0 , and a $3-\mathrm{D}$ simulation of the same storm narrowed this range to between 0.75 and 1.0 [DeCaria et al., 2005].

[4] Estimates of $\mathrm{NO}_{\mathrm{x}}$ production by lightning using laboratory experiments, theoretical assumptions regarding the physics of lightning flashes, data from field experiments, and global models were summarized by Zhang et al. [2003] and range from 8 to 5000 moles of NO per flash. Below we present estimates of $\mathrm{NO}_{\mathrm{x}}$ production per flash and per meter flash length obtained by various investigators using data from several recent field projects including STERAO (Stratosphere Troposphere Experiment: Radiation, Aerosol, Ozone) over northeastern Colorado in 1996, LINOX (Lightning-produced $\mathrm{NO}_{\mathrm{x}}$ ), in southern Germany in 1996, and EULINOX (The European Lightning Nitrogen Oxides Project) over central Europe in 1998. Estimates of $\mathrm{NO}_{\mathrm{x}}$ per lightning flash are summarized in Table 1 while estimates of $\mathrm{NO}_{\mathrm{x}}$ production per meter flash length are presented in Table 2. For the 12 July STERAO storm over Colorado, DeCaria et al. [2000] used a 2-D cloud-resolving model, and DeCaria et al. [2005] used a 3-D cloudresolving model, anvil NO observations, and observed lightning flash rates calculated from interferometer and NLDN (National Lightning Detection Network) observations to estimate $\mathrm{P}_{\mathrm{CG}}$ and the likely $\mathrm{P}_{\mathrm{IC}} / \mathrm{P}_{\mathrm{CG}}$ ratio. On the basis of analysis of lightning interferometer and aircraft data, Skamarock et al. [2003] estimated $\mathrm{NO}_{\mathrm{x}}$ production per interferometer flash and per meter flash length produced by lightning in the 10 July STERAO storm. The interferometer flash data included many short-duration flashes that likely would not be detected by other lightning detection systems. Whether or not these short-duration flashes are productive of NO is an open question. If not, then the NO production per meter in the 10 July STERAO storm would be larger than computed by Skamarock et al. [2003]. Stith et al.
[1999] estimated NO production per meter flash length on the basis of an analysis of NO spikes measured by aircraft during the same storm, as well as other STERAO storms. Using a similar approach, Huntrieser et al. [2002] estimated NO production per meter flash length for the 21 July EULINOX storm over Germany. For the same storm, an average production of NO per flash was estimated by Théry et al. [2000] on the basis of an average flash length of approximately $30 \mathrm{~km}$ calculated from interferometer data (mostly IC flashes). Through analysis of CG lightning peak current data for the 21 July EULINOX storm as recorded by BLIDS (Blitz Informationsdienst von Siemens), Fehr et al. [2004] estimated $\mathrm{P}_{\mathrm{CG}}$ and a $\mathrm{P}_{\mathrm{IC}} / \mathrm{P}_{\mathrm{CG}}$ ratio of 1.4 which was confirmed by a cloud-resolving model simulation that included a lightning parameterization, followed by comparison with anvil $\mathrm{NO}_{\mathrm{x}}$ observations. On the basis of aircraft chemical measurements from LINOX, Huntrieser et al. [1998] estimated NO production per flash while Höller et al. [1999] estimated the amount of NO produced per meter flash length for the same project using lightning observations from LPATS (Lightning Position and Tracking System). All of the above estimates of NO production are based on aircraft $\mathrm{NO}_{\mathrm{x}}$ measurements in storm anvils. In contrast, Langford et al. [2004] used remote sensing techniques to measure $\mathrm{NO}_{2}$ column abundances in the core region of a thunderstorm over Boulder, Colorado, and estimated a larger value of 963 moles of NO produced per CG flash. The wide range of values found using data from various field projects suggests that lightning $\mathrm{NO}_{\mathrm{x}}$ production may vary greatly between storms and individual flashes, though all estimates of lightning $\mathrm{NO}_{\mathrm{x}}$ production contain significant uncertainty because of the number of assumptions required in translating aircraft observations into NO production values. Further investigation is required to constrain the magnitude of NO production per flash in order to reduce uncertainty in the global source estimate.

[5] In this study, the three-dimensional (3-D) Goddard Cumulus Ensemble (GCE) model is used to simulate the dynamic evolution of the EULINOX thunderstorm observed on 21 July 1998. This output is used to drive an offline cloud-scale chemical transport model (CSCTM) which

Table 2. Estimates of NO Production per Meter Flash Channel Length

\begin{tabular}{lcl}
\hline \multicolumn{1}{c}{ Author(s) } & Field Project & Method \\
\hline Höller et al. $[1999]$ & LINOX & NO Production, \\
Huntrieser et al. $[2002]$ & EULINOX & lightning observations \\
Skamarock et al. $[2003]$ & STERAO & aircraft observations \\
& & 3-D cloud model, \\
& & aircraft observations, \\
Stith et al. $[1999]$ & STERAO & lightning observations \\
\hline
\end{tabular}


includes a parameterized lightning $\mathrm{NO}_{\mathrm{x}}$ source. The CSCTM results are first used to estimate $\mathrm{NO}_{\mathrm{x}}$ production per CG flash and per IC flash. The lightning parameterization used in this model represents an advancement over the bulk approach that was developed by DeCaria et al. [2005], in that the NO production of individual flashes is simulated in the new scheme. In an alternative parameterization, interferometer estimates of average hourly flash length during the storm are employed in the model to yield an estimate of NO production per meter flash length. The ability to estimate NO production per unit flash channel length also represents an advancement in the model over the version used in earlier work [e.g., DeCaria et al., 2005]. Chemical fields from the CSCTM are used in a chemistryonly version of the model to estimate downstream ozone production in the 24 hours following the storm.

[6] Fehr et al. [2004] also simulated the 21 July EULINOX storm using a cloud resolving model with a parameterized lightning $\mathrm{NO}_{\mathrm{x}}$ source to investigate lightning $\mathrm{NO}_{\mathrm{x}}$ production and transport, but did not examine the transport of other species, or the chemical impact of lightning $\mathrm{NO}_{\mathrm{x}}$ during or after the storm. Lightning $\mathrm{NO}_{\mathrm{x}}$ emissions were represented by a Lagrangian particle model with particles distributed within a vertical lightning channel which does not account for the tortuosity of an actual lightning flash. The Fehr et al. [2004] study also did not attempt to quantify production per meter of flash channel length. In contrast, the research reported here considers the transport of other species, the production of $\mathrm{NO}_{\mathrm{x}}$ per meter of flash channel length, and the resulting photochemical ozone production/loss.

[7] Section 2 of this paper provides background information on the EULINOX project and the investigated thunderstorm, as well as the models used. Section 3 discusses the results of the various simulations, and section 4 contains a discussion of conclusions drawn from this research.

\section{Observations and Numerical Models 2.1. Overview of the EULINOX Project and the 21 July 1998 Storm}

[8] The European Lightning Nitrogen Oxides Project (EULINOX [Höller and Schumann, 2000; Huntrieser et al., 2002]) was conducted in central Europe during June and July 1998 with the goal of better understanding lightning $\mathrm{NO}_{\mathrm{x}}$ production. During the project, airborne measurements were collected by the Deutsches Zentrum für Luft- und Raumfahrt (DLR) Falcon and Do228 research aircraft. Both measured $\mathrm{NO}_{\mathrm{x}}, \mathrm{O}_{3}, \mathrm{CO}$ and $\mathrm{CO}_{2}$, as well as meteorological parameters in and around thunderstorms in the region of the experiment. The Do228 flew primarily in the boundary layer and lower troposphere below $4 \mathrm{~km}$, while the Falcon investigated the upper troposphere and performed a number of anvil penetrations through monitored thunderstorms. $\mathrm{CG}$ lightning occurrences were recorded by an LPATS system known as BLIDS. In addition, total 3-D lightning activity $(\mathrm{IC}+\mathrm{CG})$ within the $100 \mathrm{~km}$ area surrounding the EULINOX operation center was mapped by a VHF (very high frequency) interferometer from the French Office Nationale d'Etudes et de Recherches Aerospatiales (ONERA). Both radar and satellite observations were used to monitor the development of thunderstorms in the region.
[9] On the evening of 21 July 1998 the evolution of a severe thunderstorm west of Munich, Germany was documented. Figure 1 [Höller et al., 2000] shows the evolution of the thunderstorm as observed by the Polarisation Diversity Radar (POLDIRAD) radar at $1^{\circ}$ elevation. After an initial period of intensification, the storm split into two distinct cells evident on the radar image observed at 1852 LT (1652 UTC). The northernmost cell became multicellular in structure and was observed to decay soon after the cellsplitting event, while the southern cell strengthened and developed supercell characteristics including a distinct hook echo (see radar image observed at 1933 LT [Höller et al., 2000]).

[10] From 1400 to 2200 UTC total lightning activity within the entire storm was monitored by the ONERA interferometer, and cloud-to-ground lightning activity was recorded by BLIDS. Théry [2000] compared flashes recorded by BLIDS and the ONERA interferometer and found that many low-amplitude positive flashes recorded by BLIDS were IC rather than CG. This was also true for flashes with weak negative peak current, but to a lesser degree. Flashes with peak current between -5 and $+15 \mathrm{kA}$ are removed [Höller et al., 2000] and the remaining BLIDS flashes counted to obtain CG flash rates, which were subtracted from counts of interferometer flashes to yield IC flash rates. By comparing plots of the locations of interferometer and BLIDS flashes with plots of radar reflectivity, flashes belonging to the northern and southern cells were identified. Figure 2 shows the estimated flash rates for the northern and southern cells following the cell splitting. The southern cell contained the majority of lightning activity with IC flashes dominating the total lightning activity after 1710 UTC. In the period shown, $360 \mathrm{CG}$ flashes and $2565 \mathrm{IC}$ flashes were recorded in the southern cell (mean $\mathrm{IC} / \mathrm{CG}$ ratio $=7.1$ ) while in the northern cell there were $289 \mathrm{CG}$ flashes and $815 \mathrm{IC}$ flashes (mean IC/CG ratio $=2.8$ ).

[11] The storm was penetrated seven times during the period from 1735 to 1842 UTC by the Falcon while flying between 6.3 and $9.2 \mathrm{~km}$ AGL near the active convective cells and in the lower anvil. Figure 3 [Huntrieser et al., 2002] shows the Falcon flight track superimposed on a map of VHF signals recorded by the interferometer from 1740 to 1810 UTC. During this period, nearly 400 IC and CG flashes were recorded. The Falcon flew between 8 and $9 \mathrm{~km}$ AGL in the vicinity of the maximum lightning activity where the majority of freshly produced NO would be observed. NO mixing ratios up to $25 \mathrm{ppbv}$ were observed during this period [Huntrieser et al., 2002].

[12] Fehr et al. [2004] simulated the EULINOX storm of 21 July 1998 using a modified, cloud-resolving version of the Penn State/NCAR Mesoscale Model 5 (MM5) which included a parameterized lightning $\mathrm{NO}_{\mathrm{x}}$ source with emissions represented by a Lagrangian particle model. Lightning $\mathrm{NO}_{\mathrm{x}}$ particles were distributed within a vertical flash channel with the vertical distance between particles depending on atmospheric pressure. Flash rates were parameterized using the methods of Price and Rind [1992, 1993] and Pickering et al. [1998] and compared with observed flash rates. The parameterization overestimated total lightning activity considerably, so observed flash rates were used to estimate lightning $\mathrm{NO}_{\mathrm{x}}$ production by comparing model 

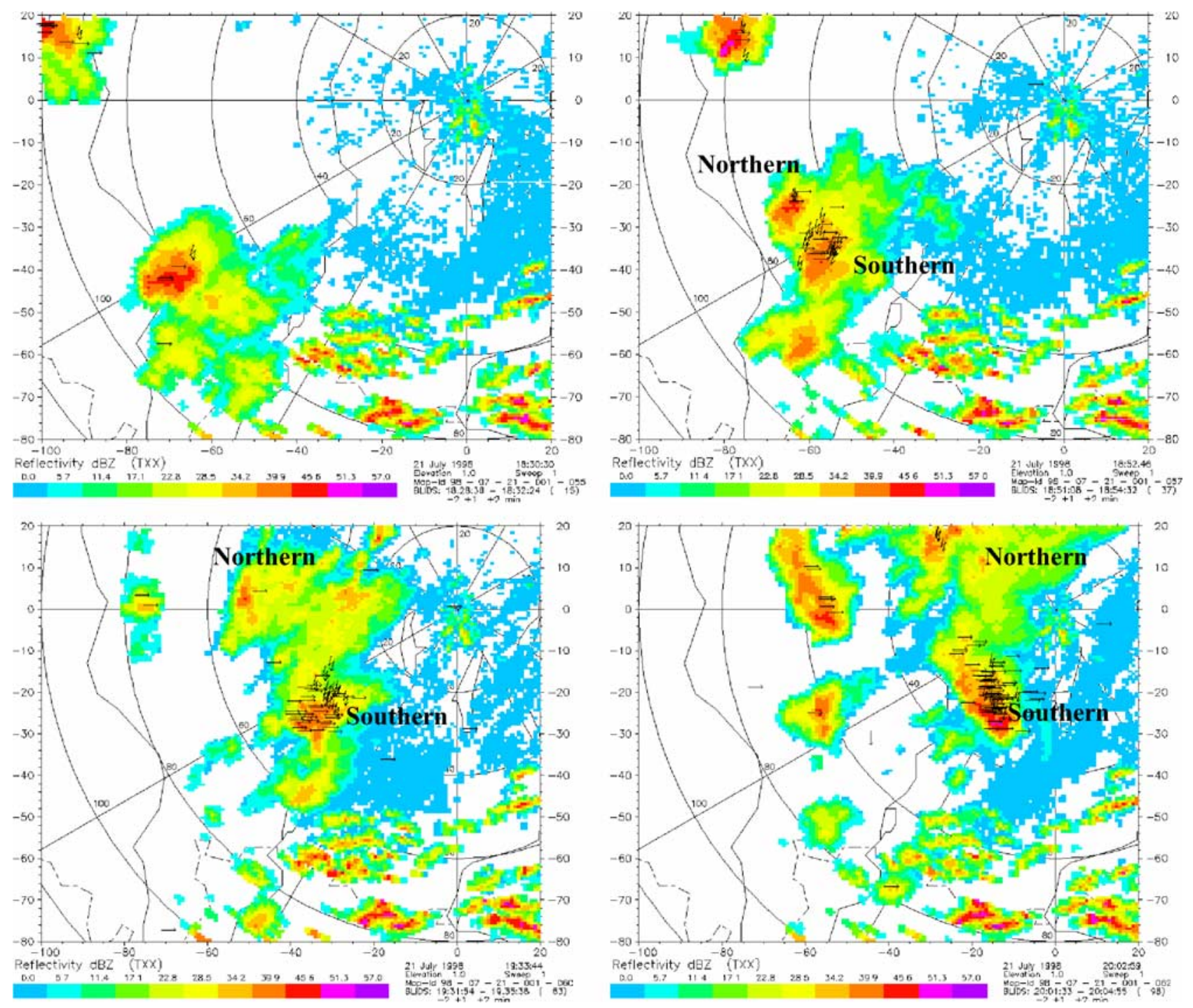

Figure 1. $1^{\circ}$ elevation scans from the POLDIRAD radar at 1640,1652, 1733, and 1802 UTC with BLIDS CG flashes recorded during the $2 \mathrm{~min}$ before and after each radar scan overlaid. Horizontal arrows denote positive flashes, and jagged arrows indicate negative flashes [Höller et al., 2000].

results with NO measurements taken during three of the seven Falcon anvil penetrations. A production scenario in which a CG flash produces approximately 330 moles of NO per flash and an IC flash is 1.4 times more productive of NO than a CG flash compared favorably with the observations used. An estimated $50-80 \%$ of the lightning produced $\mathrm{NO}_{\mathrm{x}}$ was transported to the anvil region, with $97 \%$ of anvil $\mathrm{NO}_{\mathrm{x}}$ resulting from IC flashes.

\subsection{Model Description}

[13] In order to simulate the 21 July EULINOX storm, the 3-D Goddard Cumulus Ensemble Model (GCE), a nonhydrostatic, cloud resolving model, was employed with a horizontal resolution of $2 \mathrm{~km}$ and vertical resolution of $0.5 \mathrm{~km}$. The GCE uses a Kessler-type scheme for cloud water and rain [Kessler, 1969; Houze, 1993], and a threecategory scheme from Lin et al. [1983] for cloud ice, snow, and hail to parameterize cloud microphysics. The open boundary conditions of Klemp and Wilhelmson [1978] are employed at the lateral boundaries. A complete description of the GCE model is given by Tao and Simpson [1993], with updates described by Tao et al. [2001].

[14] An associated offline 3-D Cloud-Scale Chemical Transport Model (CSCTM) was developed at the University of Maryland [DeCaria et al., 2000, 2005]. Temperature, density, wind, hydrometeor (rain, snow, graupel, cloud water, and cloud ice), and diffusion coefficient fields from the 3-D GCE are read into the model every $10 \mathrm{~min}$ in the simulation, and these fields are then interpolated to the model time step of $15 \mathrm{~s}$. The transport of chemical tracers is calculated using the van Leer advection scheme. The CSCTM employs parameterizations of lightning $\mathrm{NO}_{\mathrm{x}}$ production which use observed flash rates, avoiding the difficulty of explicit modeling of thunderstorm electrification. A passive version of the CSCTM includes only the transport of tracer species and production of lightning $\mathrm{NO}_{\mathrm{x}}$ without any chemical reactions. In the passive version, the IC- and CG- produced $\mathrm{NO}_{\mathrm{x}}$ can be isolated from preexisting $\mathrm{NO}_{\mathrm{x}}$ which allows a number of different production scenarios to 
a) July 21 Flashrates - Northern Cell

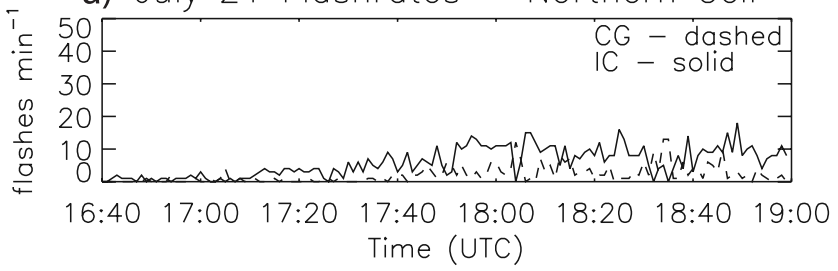

b) July 21 Flashrates - Southern Cell

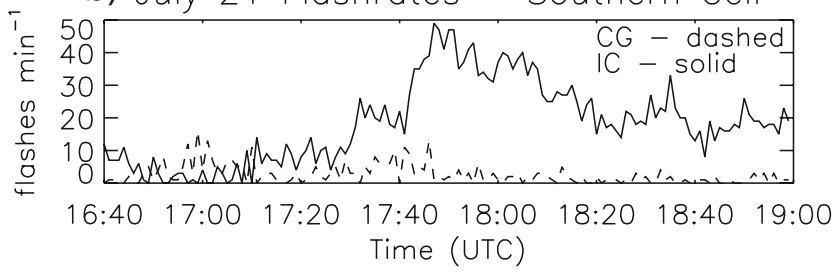

Figure 2. Time series of IC and CG flash rates for the (a) northern and (b) southern cells.

be evaluated quickly. To account for the effects of chemical reactions, the full version of the CSCTM combines tracer transport and lightning production with a chemical solver and photochemical mechanism, better simulating the actual chemical environment within the storm. The same chemistry reaction scheme as used by DeCaria et al. [2005] is employed here, except that reaction schemes for isoprene and propene were added. Soluble species are removed from the gas phase by cloud and rainwater. Multiphase reactions are not included, and photolysis rates are calculated as a function of time. A chemistry-only version of the CSCTM is used to estimate 24-hour ozone production in the convective outflow that is assumed to be transported downwind. In this version, chemical reactions and diffusion are included, while cloud-scale advection is turned off. Clear sky photolysis rates are assumed and the photolysis rates are calculated as a function of time.

[15] Two different parameterizations are used in the model to estimate the production of lightning $\mathrm{NO}_{\mathrm{x}}$. These parameterization schemes differ from the lightning $\mathrm{NO}_{\mathrm{x}}$ parameterization used by DeCaria et al. [2005] in which lightning $\mathrm{NO}_{\mathrm{x}}$ was distributed bimodally in the vertical and uniformly to all grid cells within the $20 \mathrm{dBZ}$ contour of the cloud at each level as if the $\mathrm{NO}_{\mathrm{x}}$ was instantly diffused throughout this region of the cloud. The DeCaria et al. [2005] model results were compared to the general profile shape and integrated column mass of observed NOx. This approach performed well for the 12 July STERAO storm in which the anvil observations were located relatively distant from the convective cores. In that case, the aircraft measured the integrated effects of many flashes on $\mathrm{NO}_{\mathrm{x}}$ mixing ratios. However, in the EULINOX storm the aircraft flew in a much more electrically active part of the storm, necessitating a different approach. These new parameterizations attempt to more realistically replicate actual flashes and the range of $\mathrm{NO}_{\mathrm{x}}$ mixing ratios observed by putting lightning $\mathrm{NO}_{\mathrm{x}}$ from individual flashes into smaller subsets of grid cells within the cloud.

[16] The first parameterization allows an estimate to be made of NO production per flash and the second allows an estimate of production per meter flash length. In the first scheme, observed flash rates for the northern and southern cells are input along with a scenario of IC and CG production specified in terms of moles of NO produced per flash. The average horizontal extent of a flash is calculated from interferometer data and is input for each 3 -min lightning time step, as is the total number of IC and CG flashes in each cell of the storm. The areas in which lightning occurred in the northern and southern cells were estimated from plots of observed IC and CG flashes. Areas of approximately this size were centered $10 \mathrm{~km}$ downwind of the maximum updraft of the northern and southern cells in the model because Höller et al. [2000] noted that in this storm, on the basis of an analysis of interferometer and radar observations, flashes tended to occur downwind of the updraft. The distance of $10 \mathrm{~km}$ was chosen on the basis of visual inspection of plots of radar reflectivity overlaid with flash locations presented by Höller et al. [2000].

[17] The vertical distribution of IC flash channel segments was derived from two Gaussian distributions, one centered at $-30^{\circ} \mathrm{C}$ and the other at $-15^{\circ} \mathrm{C}$, which were summed, while the vertical distribution of CG flash channel segments consisted of a single Gaussian distribution centered at $-15^{\circ} \mathrm{C}$ [DeCaria et al., 2005]. These distributions, $\mathrm{f}(\mathrm{z})$, determine the number of grid cells in the horizontal to be included in an IC or CG flash at each model level as shown in Figure 4a. The vertical distribution of the number of grid cells included in a CG flash results in no grid cells in the lowest two layers of the model receiving direct placement of lightning NO. To a first approximation, this configuration is supported by data from 3-D lightning mapping systems which record a nearly negligible amount of flash channels near the surface compared with that which

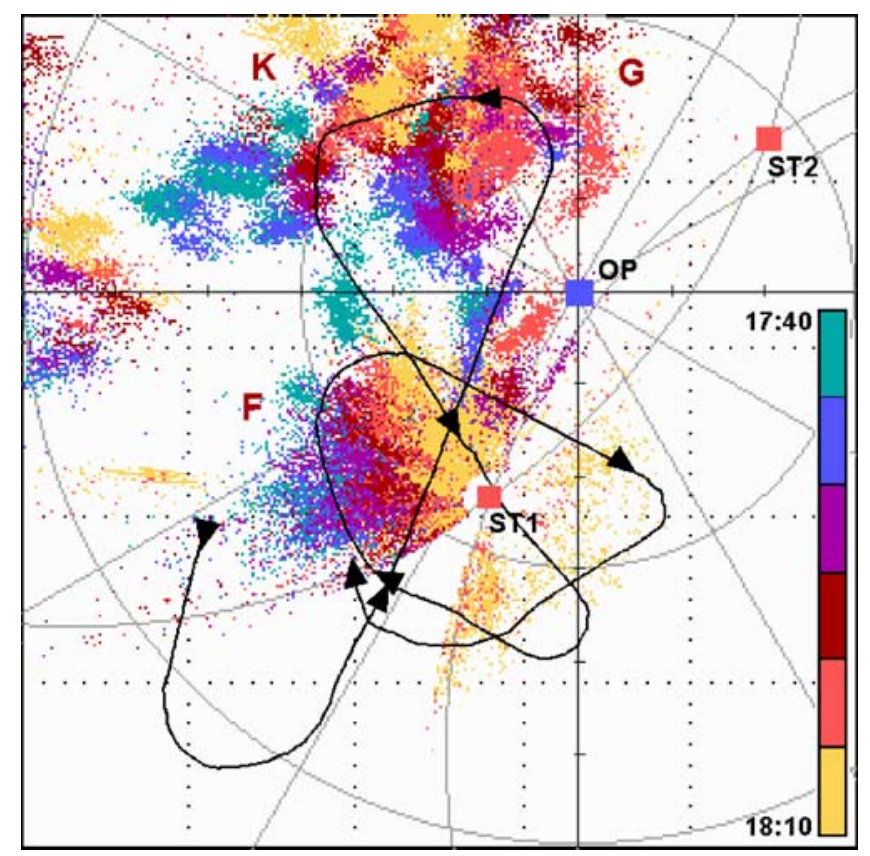

Figure 3. Locations of VHF sources recorded by interferometer at stations ST1 and ST2 between 1740 and 1810 UTC overlaid with the Falcon's trajectory during the same time period. Red letters indicate the location of electrified cells [Huntrieser et al., 2002]. 
a)

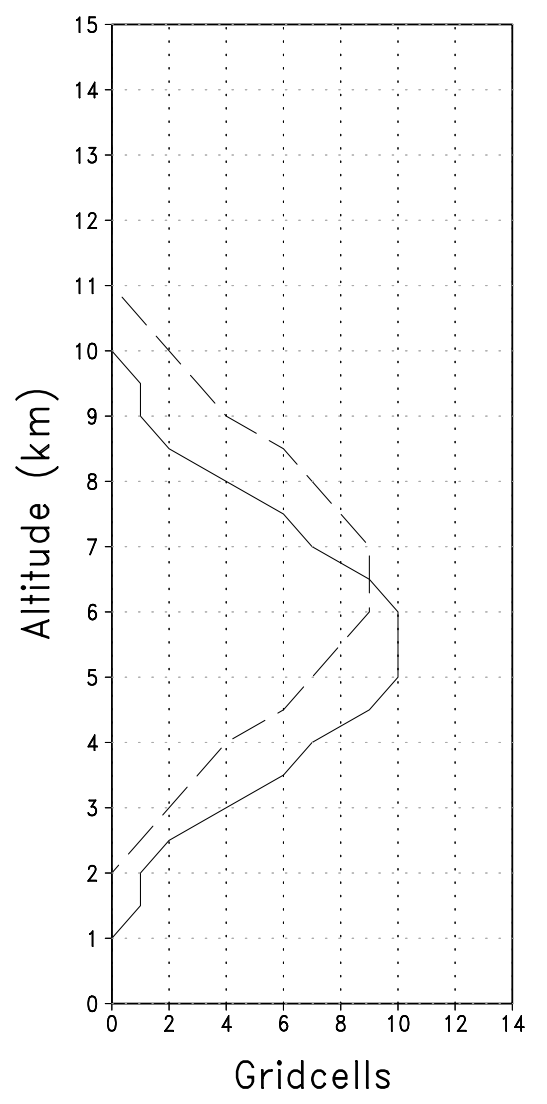

b)

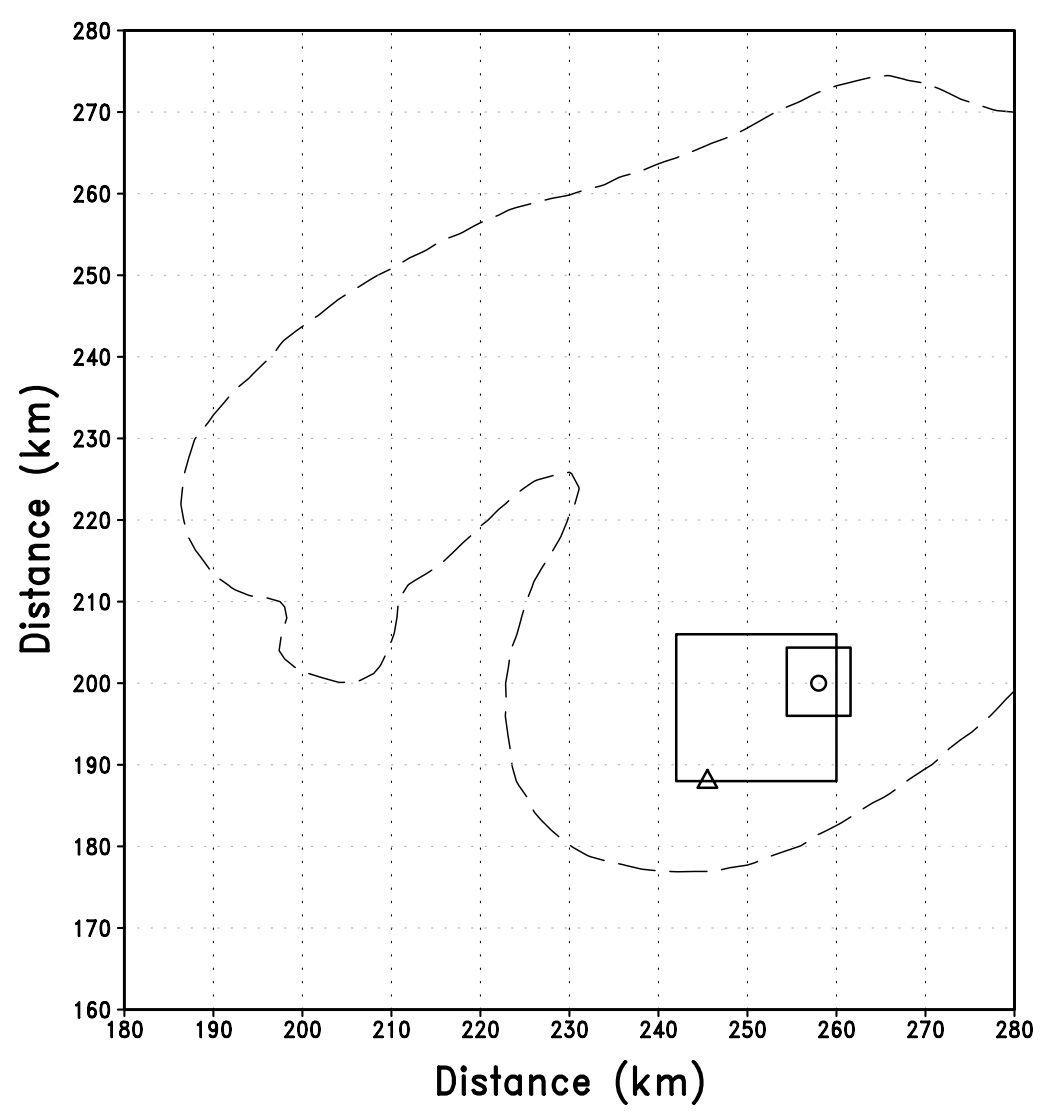

Figure 4. (a) Vertical distribution of the number of grid cells in the horizontal included at each model level in a CG flash (solid line) and in an IC flash (dotted line). (b) Schematic diagram of the lightning parameterization. Dashed line represents computed $20 \mathrm{dBZ}$ radar reflectivity contour at $9 \mathrm{~km} 150 \mathrm{~min}$ into the simulation. Triangle shows the location of the maximum updraft, and the larger box is the area from which an initiation point for the lightning is selected. The circle marks the initiation point, and the smaller box shows the area in which the flash is constrained.

occurs aloft. At the top of the cloud, as determined by the uppermost nonzero value of $\mathrm{f}(\mathrm{z})$, an initiation point is selected at random within the designated area downwind of the updraft. After this point is selected, the flash is constrained to an area equaling the average horizontal flash extent. At each level, the locations of a number of grid cells given by $\mathrm{f}(\mathrm{z})$ are selected at random, such that tortuosity of the flash is simulated. NO production is distributed to all grid cells along each flash with a dependence on pressure as described by DeCaria et al. [2000] because of laboratory experiments showing a linear relationship between pressure and NO production [Wang et al., 1998]. Figure 4b shows a schematic diagram of lightning NO placement in the southern cell. The dashed line represents the $20 \mathrm{dBZ}$ contour at $9 \mathrm{~km}$ $150 \mathrm{~min}$ into the simulation. The maximum updraft velocity location is identified by the triangle. The larger box centered downstream of the updraft velocity maximum designates the area from which an initiation point for the flash, marked with an open circle, is selected. The smaller box centered about the initiation point is the area determined by the average horizontal flash extent. Various $\mathrm{NO}_{\mathrm{x}}$ production scenarios are simulated to determine which most closely matches observed $\mathrm{NO}_{\mathrm{x}}$ mixing ratios in the electrically active region.

[18] The second parameterization scheme is similar to the first, except that the specified production is per meter of flash channel length and production per flash is calculated by the model using the average hourly length per flash as given by Théry et al. [2000]. Lightning flashes are constructed in the same manner as in the first parameterization, and the most appropriate production per meter flash length is estimated by comparing results from various production scenarios with aircraft observations.

\section{Results}

\subsection{Cloud Simulation}

[19] The GCE model was initialized with a single sounding that included data from a German Weather Service radiosonde, the ascent of the DLR Falcon aircraft, and a dropsonde released during the Falcon's flight, all of which were no more than $90 \mathrm{~min}$ ahead of the storm. CAPE for this sounding was $1590 \mathrm{~J} / \mathrm{kg}$ [Fehr et al., 2004]. The sounding also shows winds veering at low levels which is conducive to splitting. Convection was initiated with a 
a) Radar Reflectivity (dBZ) $Z=1 \mathrm{~km} 30 \mathrm{~min}$

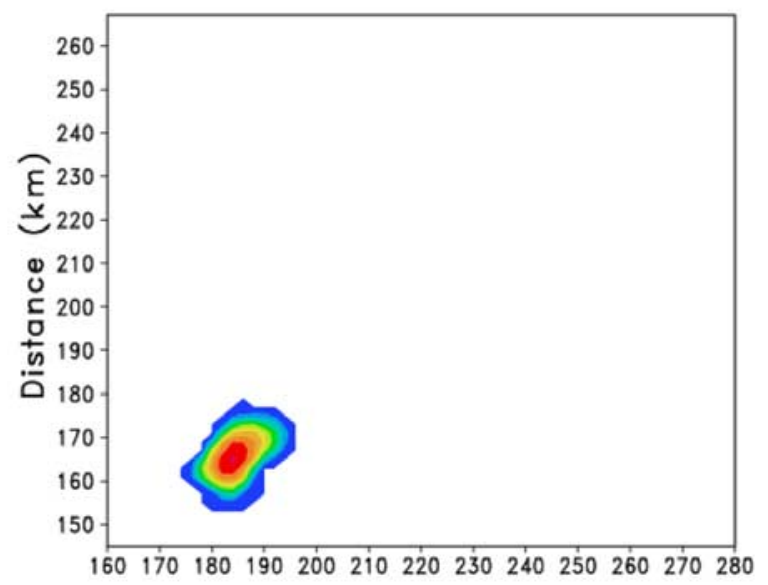

c) Radar Reflectivity(dBZ) $Z=1 \mathrm{~km} 150 \mathrm{~min}$

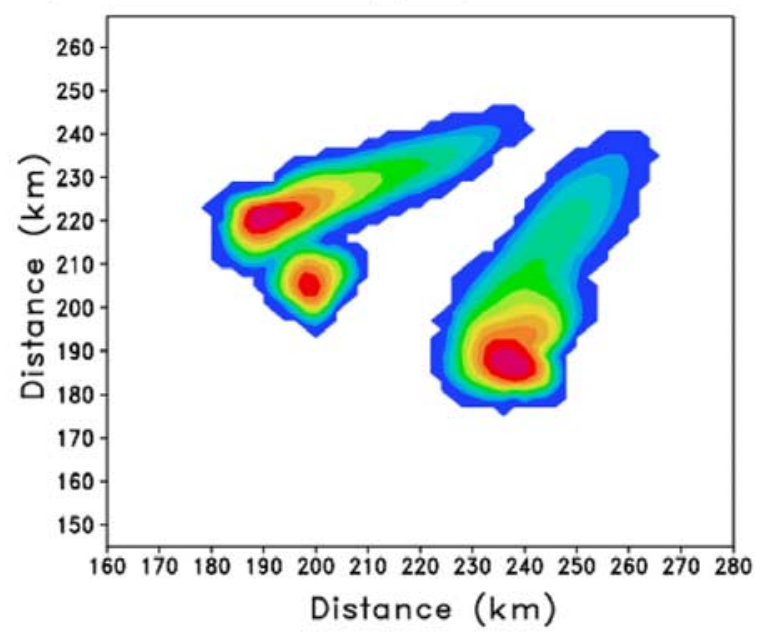

b) Radar Reflectivity(dBZ) $Z=1 \mathrm{~km} 100 \mathrm{~min}$

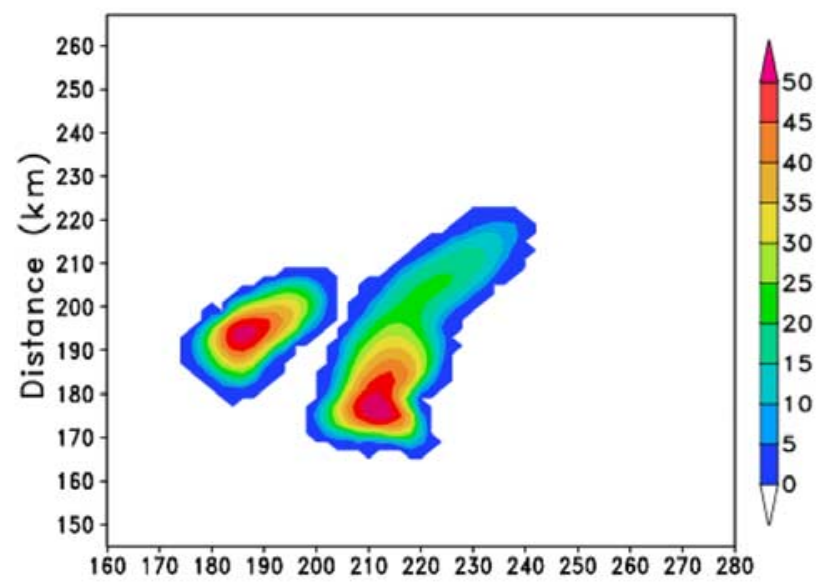

d) Radar Reflectivity(dBZ) $Z=1 \mathrm{~km} 180 \mathrm{~min}$

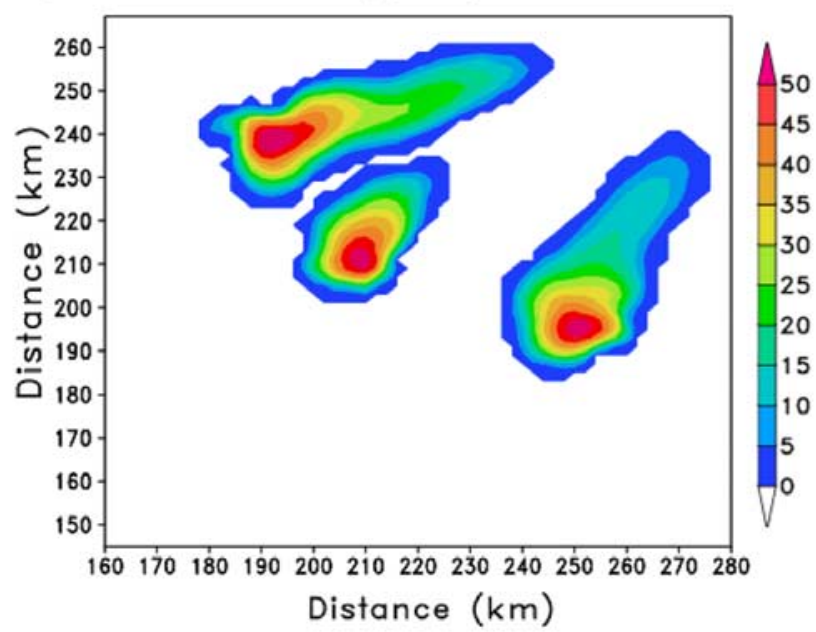

Figure 5. Radar reflectivity at $1 \mathrm{~km}$ elevation computed from GCE hydrometeor fields at (a) 30, (b) 100, (c) 150 , and (d) $180 \mathrm{~min}$ in the simulation.

warm thermal perturbation. The model domain was $360 \times$ $328 \mathrm{~km}$, with a horizontal resolution of $2 \mathrm{~km}$. There were 50 vertical levels, with a resolution of $0.5 \mathrm{~km}$. The model was run for 6 hours.

[20] The GCE simulation successfully reproduced a number of features of the observed storm. A single cell first appears $20 \mathrm{~min}$ into the simulation. At $70 \mathrm{~min}$, the cell splitting begins. Because the early stages of the cell splitting is observed on radar at $\sim 1650$ UTC (Figure 1), $70 \mathrm{~min}$ in the simulation was chosen to correspond to this time for the purposes of comparison with aircraft observations and the use of observed flash rates in the lightning parameterization. Thus the beginning of the simulation is assumed to correspond to 1540 UTC. Figure 5 shows a time series of radar reflectivity plots calculated from the GCE model hydrometeor mixing ratios at $1 \mathrm{~km}$. A single cell is observed at $30 \mathrm{~min}$ into the simulation. The cell has completely split in two at $100 \mathrm{~min}$ in the model simulation. The southern cell developed a supercell circulation and has an apparent hook echo at this time. At $150 \mathrm{~min}$, a third cell has developed between the original two cells. The southern cell has begun to decay at $180 \mathrm{~min}$, and the northern cell becomes dominant.

[21] Some simulated storm features are similar to observations and some differ. The model correctly predicted the splitting of the initial cell. However, in the observed system the northern cell weakened rapidly after the cell splitting event and the southern cell became the dominant feature, evolving into a supercell. The simulated southern cell, while demonstrating supercell characteristics and dominating for a period of time, did not persist as long as observed. Cloud top heights reached $14 \mathrm{~km}$ which compares favorably with observations [Höller et al., 2000] and the MM5 simulation presented by Fehr et al. [2004]. Discrepancies between the simulated storm and observations may be because the nonuniformity of terrain and initial conditions [Stenchikov et al., 2005] were not accounted for in the GCE simulation. Boundary conditions may also have contributed to these differences. However, comparison with observations showed that simulated storm evolution is fairly reasonable for the period of $180 \mathrm{~min}$ that was chosen for the chemistrytransport calculations in this study. 
a)

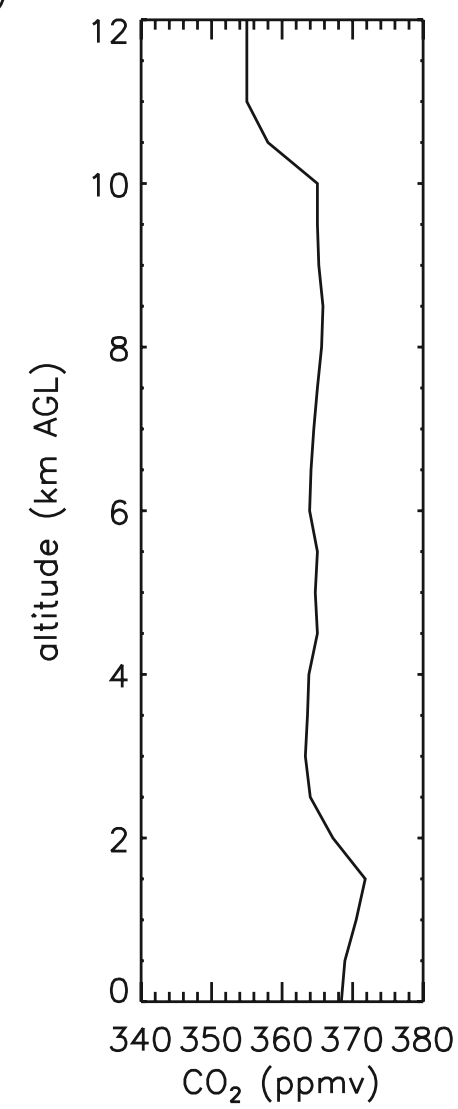

b)

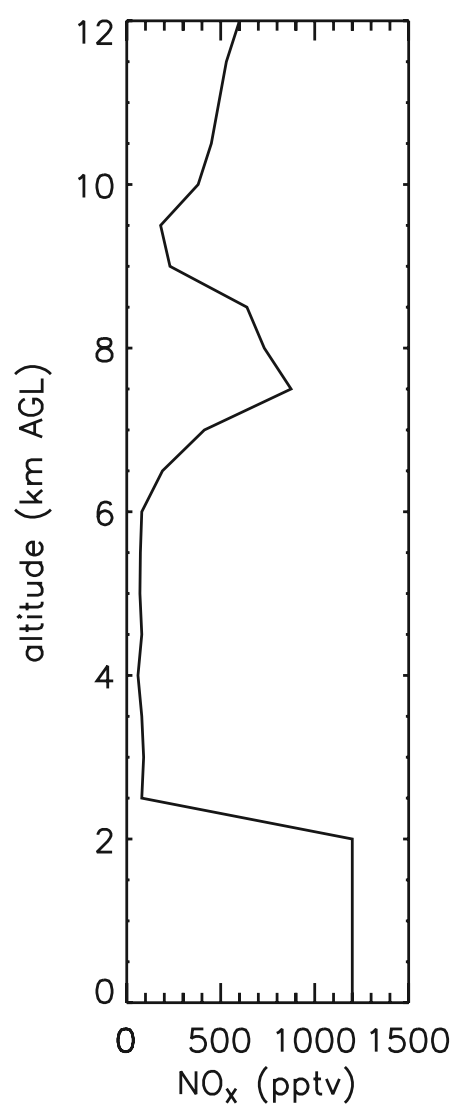

c)

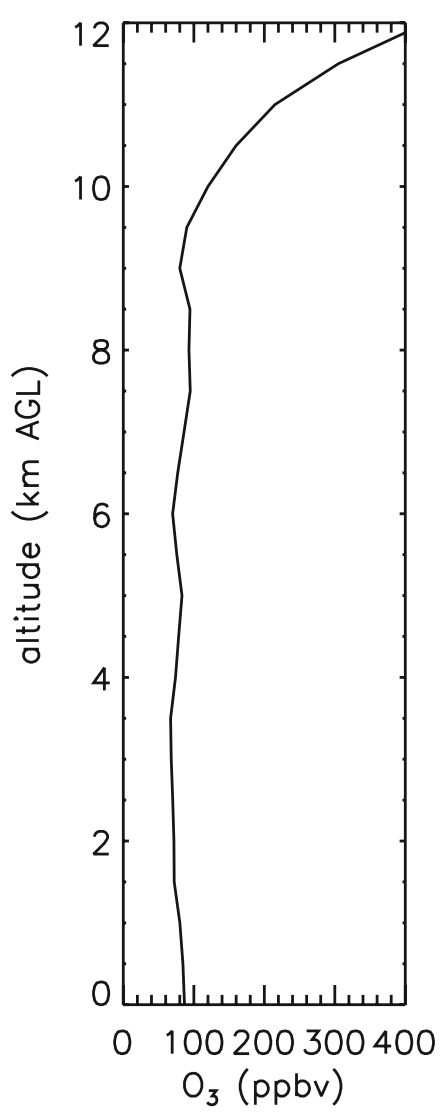

Figure 6. Initial condition profiles of (a) $\mathrm{CO}_{2}$, (b) $\mathrm{NO}_{\mathrm{x}}$, and (c) $\mathrm{O}_{3}$.

[22] At 1657 UTC, just after the cell splitting event, the southern cell was observed by dual-Doppler radar and the 3-D wind field reconstructed. At this time, a maximum updraft speed of $24 \mathrm{~m} \mathrm{~s}^{-1}$ was observed while the strongest downdraft was $9 \mathrm{~m} \mathrm{~s}^{-1}$ [Höller et al., 2000]. At the corresponding time in the simulation $(80 \mathrm{~min})$, the maximum updraft velocity was $34 \mathrm{~m} \mathrm{~s}^{-1}$ while the maximum downdraft was $7 \mathrm{~m} \mathrm{~s}^{-1}$. Because of the location of the storm with respect to the radars, dual-Doppler analysis was not possible at other times. Maximum updraft velocities were approximately $36 \mathrm{~m} \mathrm{~s}^{-1}$ between 90 and $130 \mathrm{~min}$ in the simulation, and then decreased. This is lower than the maximum updraft of $49 \mathrm{~m} \mathrm{~s}^{-1}$ reported in the Fehr et al. [2004] simulation. Downdraft velocities were also less than those presented by Fehr et al. [2004] in which a maximum of $25 \mathrm{~m} \mathrm{~s}^{-1}$ was recorded. Throughout the GCE simulation, downdraft velocities were typically less than $10 \mathrm{~m} \mathrm{~s}^{-1}$. Low-level inflow to the storm occurred between 0.5 and $3 \mathrm{~km}$ while outflow from the anvil was greatest between 9 and $11 \mathrm{~km}$.

\subsection{Passive Model Results}

[23] The passive version of the CSCTM was used to calculate the transport of $\mathrm{CO}_{2}, \mathrm{NO}_{\mathrm{x}}$, and $\mathrm{O}_{3} . \mathrm{CO}$, which in polluted regions has a stronger vertical gradient and would be preferable to $\mathrm{CO}_{2}$ as a tracer of upward transport, was not measured on this day. An initial profile of $\mathrm{CO}_{2}$ data was constructed using data from the Falcon ascent and a value of $355 \mathrm{ppbv}$ above the tropopause taken from Strahan et al.
[1998]. An initial profile of $\mathrm{O}_{3}$ was constructed from data from the Falcon ascent, the DO-228 boundary layer data for the day, and a climatological average ozone profile for the latitude of Munich above $9 \mathrm{~km}$. The $\mathrm{NO}_{\mathrm{x}}$ profile was composed of data taken from the Falcon ascent in the free troposphere and from a profile one standard deviation greater than the average $\mathrm{NO}_{\mathrm{x}}$ boundary layer profile during the EULINOX project [Huntrieser et al., 2002]. A profile with values larger than the project mean in the boundary layer was assumed because no actual measurements were available and high measured boundary layer values of $\mathrm{CO}_{2}$ and $\mathrm{O}_{3}$ suggested polluted $\mathrm{NO}_{\mathrm{x}}$ conditions on this day. Sensitivity calculations were also performed using the EULINOX boundary layer average and the boundary layer average plus two standard deviations in order to assess the effects of this uncertainty on the lightning NO production results. Initial condition profiles for $\mathrm{CO}_{2}, \mathrm{NO}_{x}$, and $\mathrm{O}_{3}$ are shown in Figure 6. IC and CG flash rates for the northern and southern cells (as shown in Figure 2) were read into the model at 3-min intervals beginning $21 \mathrm{~min}$ into the simulation to correspond to the time when lightning was first observed, and the amount of lightning $\mathrm{NO}_{\mathrm{x}}$ produced in each time interval is calculated.

\subsection{1. $\mathrm{CO}_{2}$ and $\mathrm{O}_{3}$ Results}

[24] Figure 7 shows a vertical cross section of $\mathrm{CO}_{2}$ through the southern cell at 150 min when the cell was at maximum strength, oriented $65^{\circ}$ Counterclockwise from due east. Air containing the maximum $\mathrm{CO}_{2}$ mixing ratios exceeding $370 \mathrm{ppmv}$ initially in the $1-2 \mathrm{~km}$ region has 


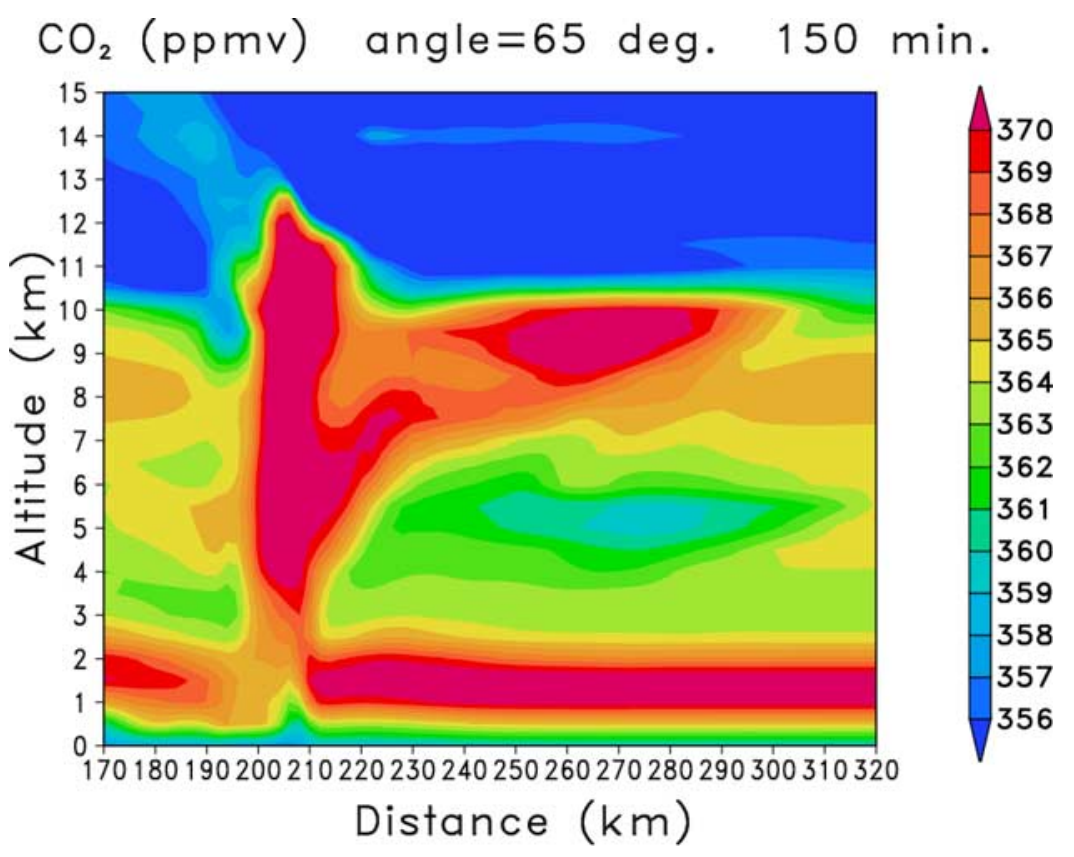

Figure 7. Cross section of $\mathrm{CO}_{2}$ mixing ratios in the southern cell from the CSCTM at 150 min at an angle of $65^{\circ}$ counterclockwise from east.

been transported to over $12 \mathrm{~km}$ in the core updraft region, and as high as $10 \mathrm{~km}$ in the anvil, indicating strong upward motion. Both the core and the downwind anvil regions of the storm are largely composed of air that resided in the boundary layer prior to convection, while there is little evidence of entrainment of environmental air with lower $\mathrm{CO}_{2}$ mixing ratios. The model also suggests downward transport of smaller mixing ratios of $\mathrm{CO}_{2}$ in the $8-11 \mathrm{~km}$ altitude region behind the storm.

[25] In order to compare simulated tracer transport with mixing ratios observed during the series of seven anvil penetrations, data collected by the Falcon aircraft were averaged over approximately 11-s intervals to yield a spatial resolution equivalent to the model, and then binned into $0.5 \mathrm{~km}$ thick layers. Unfortunately, in-cloud observations were only available for three $0.5 \mathrm{~km}$ thick layers centered at $8,8.5$ and $9 \mathrm{~km}$ AGL. Therefore the comparison with model results includes only a $1.5-\mathrm{km}$ thick layer. The analysis would have benefited from observations at a wide range of altitudes as were available for the 12 July STERAO-A storm simulated by DeCaria et al. [2005] in which the aircraft executed a spiral ascent through the storm anvil, measuring NO from 7 to $11 \mathrm{~km}$ MSL. The area covered by each penetration was calculated from flight position data. The average distance covered during 6 of the 7 anvil penetrations was determined to be approximately $24 \mathrm{~km}$ in the x-direction and $36 \mathrm{~km}$ in the y-direction. A box of this size was placed around the core of the southern cell where radar observations and flight data show the Falcon was primarily sampling. The grid cells within this box were sampled at times in the simulation corresponding to the times of the aircraft sampling at each level, and cumulative probability distribution functions (pdfs) were calculated for each level. In addition, the mean, mode and standard deviation of observed and simulated $\mathrm{NO}_{\mathrm{x}}, \mathrm{O}_{3}$ and $\mathrm{CO}_{2}$ mixing ratios at $9 \mathrm{~km}$ were calculated and are shown in
Table 3. The model did an excellent job in estimating the mean values at this altitude. However, it appears that the distribution of observed $\mathrm{O}_{3}$ mixing ratios at this level is substantially broader than that simulated.

[26] Figure 8 shows the calculated pdfs of observed and simulated $\mathrm{CO}_{2}$ at $8,8.5$ and $9 \mathrm{~km} \mathrm{AGL}$. At all three levels, the distribution of simulated $\mathrm{CO}_{2}$ matches the observed distribution well with a slight overestimation of the maximum values. At $9 \mathrm{~km}$, the model also underestimates the minimum values, suggesting that the downward transport at the rear of the storm may not have been as pronounced as seen in the model. Figure 9 shows pdfs of observed and simulated $\mathrm{O}_{3}$ at 8 and $9 \mathrm{~km}$, the only two levels for which a sufficient number of observations were available to calculate pdfs. At both levels, the simulations underestimate the maximum values and overestimate the minimum values. The overestimation of minimum values is due in part to the initial condition profiles used. Though ozone as low as $63 \mathrm{ppbv}$ was observed in the storm, the lowest value in the initial condition profile was $67 \mathrm{ppbv}$ at $3.5 \mathrm{~km}$ because there was no observational evidence outside the storm to suggest that values lower than this would be appropriate. When chemical reactions are included in the model (see section 3.3.) a small loss of ozone occurs at $8 \mathrm{~km}$, slightly

Table 3. Statistics of Observed and Simulated Tracer Mixing Ratios at $9 \mathrm{~km}^{\mathrm{a}}$

\begin{tabular}{llll}
\hline & Mean & Mode & Standard Deviation \\
\hline Observed $\mathrm{CO}_{2}$, ppmv & 367.0 & 366.4 & 1.5 \\
Simulated $\mathrm{CO}_{2}$, ppmv & 367.8 & 371.8 & 3.4 \\
Observed $\mathrm{O}_{3}$, ppbv & 90.0 & 84.8 & 15.8 \\
Simulated $\mathrm{O}_{3}$, ppbv & 89.1 & 84.1 & 5.6 \\
Observed $\mathrm{NO}_{x}$, ppbv & 2.4 & 1.3 & 1.7 \\
Simulated $\mathrm{NO}_{\mathrm{x}}$, ppbv & 2.62 & 0.3 & 2.1 \\
\hline
\end{tabular}

${ }^{a}$ Statistics are computed over the sampling box shown in Figure 12a. 

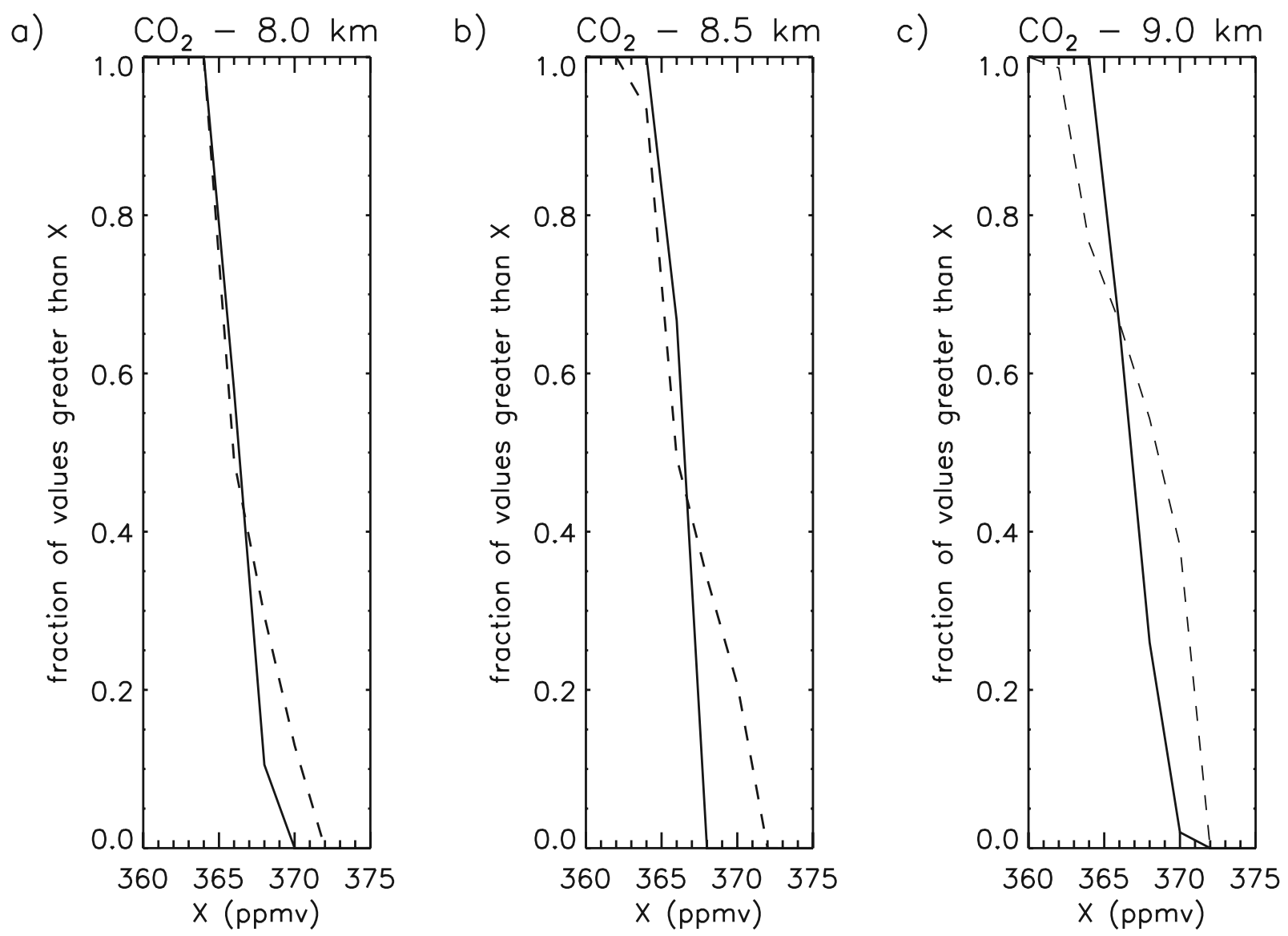

Figure 8. Pdfs of observed (solid) and simulated (dashed) $\mathrm{CO}_{2}$ mixing ratios at (a) 8, (b) 8.5, and (c) $9 \mathrm{~km}$.

improving the comparison between the simulated and observed minimum values though overestimation of the minimum values is still noticeable, particularly at $9 \mathrm{~km}$. The underestimation of the maximum values suggests the model may be underrepresenting downward transport, although this is not supported by analysis of the $\mathrm{CO}_{2}$ distributions. This contradiction may be the result of a lack of sufficient observations of $\mathrm{CO}_{2}$ and $\mathrm{O}_{3}$ near the tropopause to well define the vertical gradients in this region that are used in the initial condition profiles. Additionally, the observed discrepancy could be caused by time interpolation of the driving field and approximation errors. If downward transport is slightly underrepresented by the model, it is unlikely to significantly affect the estimates of lightning $\mathrm{NO}_{\mathrm{x}}$ production because $\mathrm{NO}_{\mathrm{x}}$ mixing ratios immediately above the tropopause are similar to the enhanced mixing ratios of $\mathrm{NO}_{\mathrm{x}}$ between 7 and $9.5 \mathrm{~km}$ in the initial condition profile.

\subsection{2. $\mathrm{NO}_{\mathrm{x}}$ Results}

[27] To calculate lightning $\mathrm{NO}_{\mathrm{x}}$ production, $\mathrm{P}_{\mathrm{CG}}$ was estimated to be approximately 360 moles of NO per flash on the basis of observed peak current and a relationship between peak current and energy dissipated from Price et al. [1997]. Several different values of the $\mathrm{P}_{\mathrm{IC}} / \mathrm{P}_{\mathrm{CG}}$ ratio were simulated and the results compared with observations. The common assumption that $\mathrm{P}_{\mathrm{IC}}$ is one tenth $\mathrm{P}_{\mathrm{CG}}$ from Price et al. [1997] was simulated and the pdf of observed and simulated $\mathrm{NO}_{\mathrm{x}}$ at $9 \mathrm{~km}$ is shown in Figure 10a. The assumption that IC flashes are significantly less productive of NO than $\mathrm{CG}$ flashes clearly underestimates $\mathrm{NO}_{\mathrm{x}}$ at all levels. Fehr et al. [2004] found a $\mathrm{P}_{\mathrm{IC}} / \mathrm{P}_{\mathrm{CG}}$ ratio of $1.4 \mathrm{most}$ appropriate for a simulation of the same storm. Figure $10 \mathrm{~b}$ shows the $9 \mathrm{~km}$ pdf with $\mathrm{NO}_{\mathrm{x}}$ production based on this assumption. At this level, where the majority of $\mathrm{NO}_{\mathrm{x}}$ observations were taken, assuming a $\mathrm{P}_{\mathrm{IC}} / \mathrm{P}_{\mathrm{CG}}$ ratio of 1.4 results in an overestimation of the lightning $\mathrm{NO}_{\mathrm{x}}$ source. At 8 and $8.5 \mathrm{~km}$, fewer observations are available, but the maximum observed mixing ratios exceeding 15 and $20 \mathrm{ppbv}$ were reasonably simulated at these levels using the ratio of 1.4. Therefore the comparison of the $\mathrm{P}_{\mathrm{IC}} / \mathrm{P}_{\mathrm{CG}}=$ 1.4 scenario with observations at these two levels is better than at $9 \mathrm{~km}$.

[28] A scenario in which $\mathrm{P}_{\mathrm{IC}}$ is equal to $\mathrm{P}_{\mathrm{CG}}$ was also simulated and the pdfs for $8,8.5$, and $9 \mathrm{~km}$ are shown in Figure 11. At $9 \mathrm{~km}$, the comparison between the observed and simulated distributions is much better than in the $\mathrm{P}_{\mathrm{IC}} /$ $P_{C G}$ of 0.1 and 1.4 scenarios shown in Figure 10. At 8 and $8.5 \mathrm{~km}$, the model is able to reproduce the distribution below 6 ppbv fairly well, but fails to produce the large $\mathrm{NO}_{\mathrm{x}}$ mixing ratios observed. Figure 12 a shows a plot of $\mathrm{NO}_{\mathrm{x}}$ at $9 \mathrm{~km} 180 \mathrm{~min}$ into the $\mathrm{P}_{\mathrm{IC}}=\mathrm{P}_{\mathrm{CG}}$ simulation with the box used for sampling model output. $\mathrm{NO}_{\mathrm{x}}$ mixing ratios exceeding 9 ppbv are evident in the core of the southern cell and mixing ratios over 2 ppbv extend outward in the anvil a 

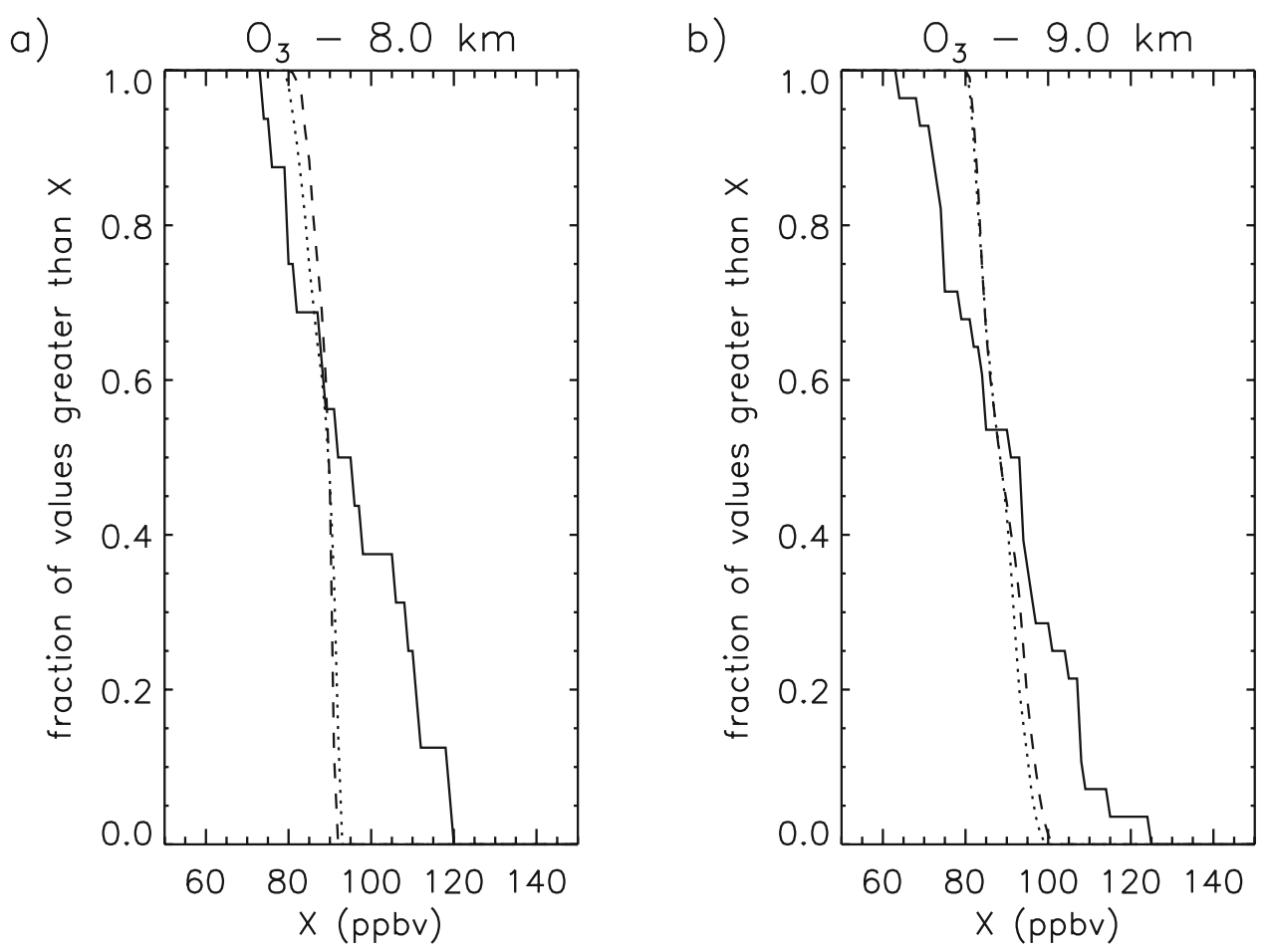

Figure 9. Pdfs of observed (solid) and simulated (without chemical reactions indicated by dashed, with chemical reactions indicated by dotted) $\mathrm{O}_{3}$ mixing ratios at (a) 8 and (b) $9 \mathrm{~km}$.

distance of over $70 \mathrm{~km}$. Figure 13 shows the average profiles of $\mathrm{NO}_{\mathrm{x}}$ mixing ratio within the averaging box at the beginning of the simulation, after $180 \mathrm{~min}$ of simulation of $\mathrm{NO}_{\mathrm{x}}$ transport without lightning $\mathrm{NO}$ production, and at $180 \mathrm{~min}$ with the inclusion of lightning NO production. The transport-only simulation results in a mean profile over the averaging box which maximizes at only $1 \mathrm{ppbv}$ at anvil levels, but this represents an approximate doubling of the amount of $\mathrm{NO}_{\mathrm{x}}$ at this level compared with the initial profile. The inclusion of lightning $\mathrm{NO}_{\mathrm{x}}$ in the model results
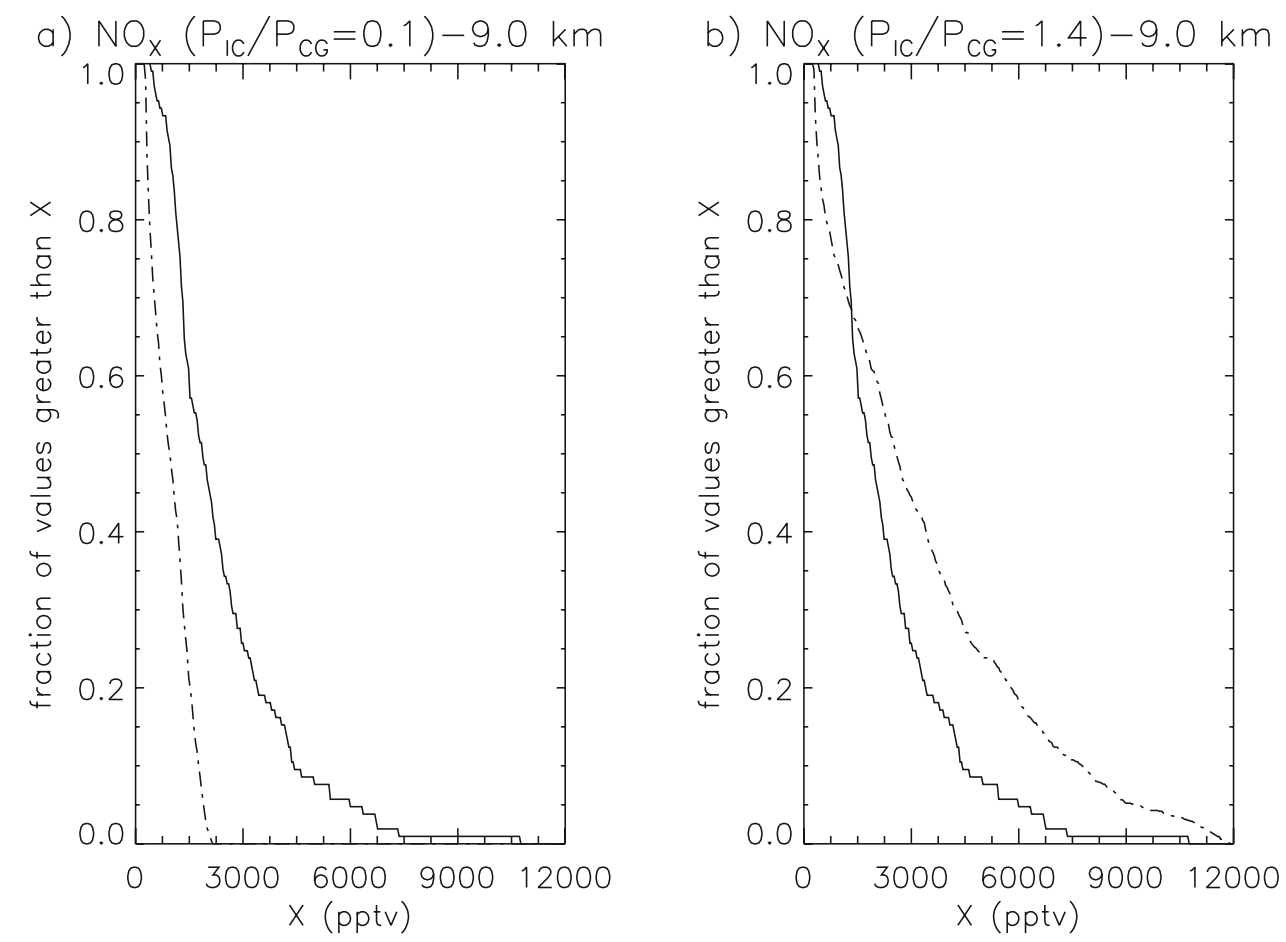

Figure 10. Pdfs of observed (solid) and simulated (dashed) $\mathrm{NO}_{\mathrm{x}}$ mixing ratios at $9 \mathrm{~km}$ assuming (a) $\mathrm{P}_{\mathrm{IC}} / \mathrm{P}_{\mathrm{CG}}=0.1$ and (b) $\mathrm{P}_{\mathrm{IC}} / \mathrm{P}_{\mathrm{CG}}=1.4$. 

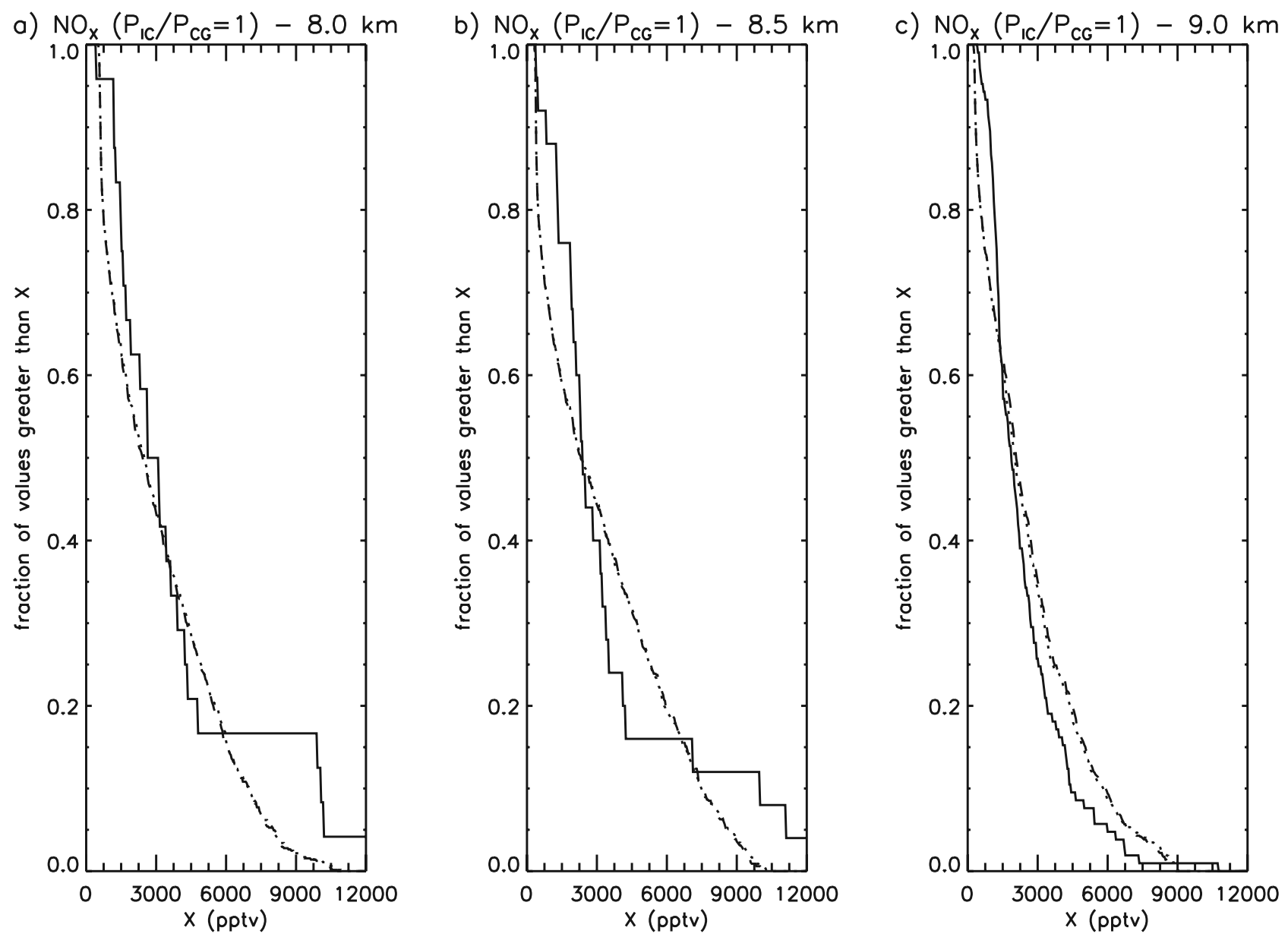

Figure 11. Pdfs of observed (solid) and simulated (assuming $P_{I C}=P_{C G}=360$ moles NO (dashed) and assuming $\mathrm{P}=1.25 \times 10^{-2}$ moles $\mathrm{NO}$ per meter flash channel length (dotted)) $\mathrm{NO}_{\mathrm{x}}$ mixing ratios at (a) 8 , (b) 8.5 , and (c) $9 \mathrm{~km}$ assuming $\mathrm{P}_{\mathrm{IC}} / \mathrm{P}_{\mathrm{CG}}=1.0$.

in an increase in this anvil maximum to approximately 4 ppbv at $10 \mathrm{~km}$ with a second peak of 4 ppbv at $5.5 \mathrm{~km}$.

[29] To determine which production scenario was the most appropriate, the mass of $\mathrm{N}$ in $\mathrm{NO}_{\mathrm{x}}$ in the column between 7.75 and $9.25 \mathrm{~km}$ was also calculated by averaging observations and model results in each of the three $0.5 \mathrm{~km}$ layers. The observations yield a column mass of $1.13 \times$ $10^{-3} \mathrm{~g} \mathrm{~N} \mathrm{~m}^{-2}$. The accuracy of the $\mathrm{NO}$ and $\mathrm{NO}_{2}$ instruments are 5 and $10 \%$ respectively [Huntrieser et al., 2002]. Therefore, in terms of measurement error in the column mass estimate, $10 \%$ would be an upper limit. However, there is additional uncertainty because it is impossible to know how well the aircraft observations represent a particular area within the storm. Assuming a production scenario in which an IC flash produces only one tenth as much NO as a CG flash greatly underestimates column mass, producing $3.43 \times 10^{-4} \mathrm{~g} \mathrm{~N} \mathrm{~m}^{-2}$. The assumption from Fehr et al. [2004] that an IC flash produces 1.4 times as much NO as a $\mathrm{CG}$ flash leads to a column mass of $1.36 \times 10^{-3} \mathrm{~g} \mathrm{~N} \mathrm{~m}^{-2}$, an overestimation of approximately $20 \%$. Of the three scenarios presented, assuming an IC flash produces as much $\mathrm{NO}$ as a $\mathrm{CG}$ flash provides the best comparison with observations with a column mass of $1.05 \times 10^{-3} \mathrm{~g} \mathrm{~N} \mathrm{~m}^{-2}$, which underestimates the column mass calculated from observations by approximately $7 \%$. The inclusion of chemical reactions in the model tends to decrease $\mathrm{NO}_{\mathrm{x}}$, slightly increasing the error in column mass of the production scenario in which $\mathrm{P}_{\mathrm{IC}}=\mathrm{P}_{\mathrm{CG}}=360$ moles $\mathrm{NO}$ per flash to $10.5 \%$ (see section 3.3). On the basis of the comparison of the pdfs and column mass of the observed and simulated storms, this scenario is selected as the most appropriate of the three for this storm. An increase or decrease of one standard deviation in the boundary layer $\mathrm{NO}_{\mathrm{x}}$ resulted in a change of only $3 \%$ in the calculated column mass of $\mathrm{N}$ in $\mathrm{NO}_{\mathrm{x}}$. Therefore the assumption of boundary layer $\mathrm{NO}_{\mathrm{x}}$ mixing ratio has little impact on our ability to deduce the appropriate lightning $\mathrm{NO}_{\mathrm{x}}$ production scenario.

[30] A second parameterization scheme was used to estimate NO production per meter flash channel length. In this parameterization, various values of production per meter are specified, and production per IC and CG flash is calculated using hourly average interferometer-observed flash lengths of 21.5, 27.9, and $31.4 \mathrm{~km}$ from Théry et al. [2000] for the hours beginning at 1600, 1700 and 1800 UTC, respectively. By calculating pdfs (Figure 11) and column mass, a production of $1.25 \times 10^{-2}$ moles NO per meter of flash channel length was found to yield results comparable to the $\mathrm{P}_{\mathrm{IC}}=\mathrm{P}_{\mathrm{CG}}=360$ moles NO per flash 

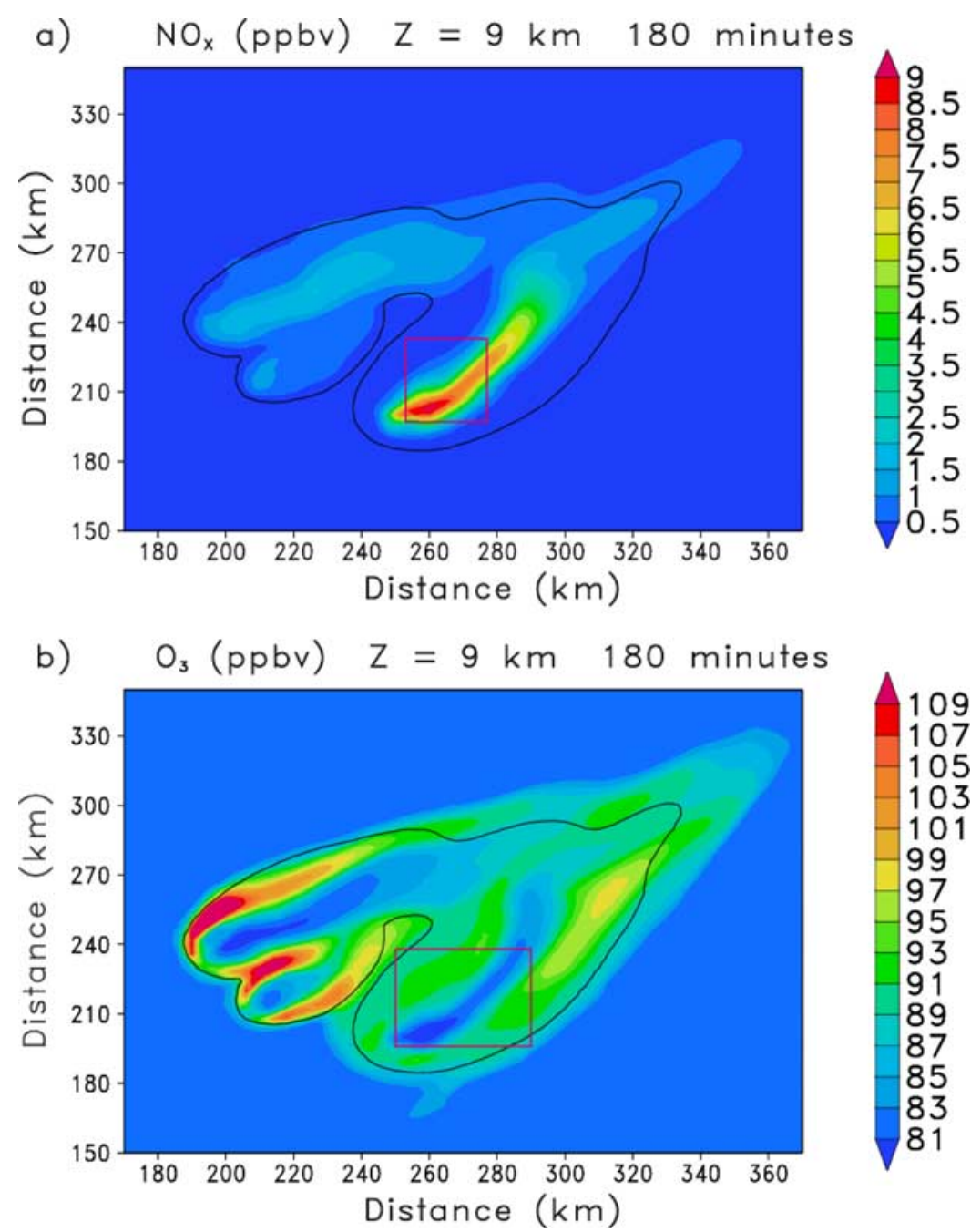

Figure 12. (a) $\mathrm{NO}_{\mathrm{x}}$ mixing ratios at $9 \mathrm{~km}$ elevation assuming $\mathrm{P}_{\mathrm{IC}}=\mathrm{P}_{\mathrm{CG}}=360$ moles $\mathrm{NO} / \mathrm{flash}$ at $180 \mathrm{~min}$ in the passive CSCTM simulation. The box indicates the grid cells sampled for calculation of column mass and pdfs, and the black line indicates the $20 \mathrm{dBZ}$ contour of computed radar reflectivity. (b) $\mathrm{O}_{3}$ mixing ratios at $9 \mathrm{~km}$ at $180 \mathrm{~min}$ in the CSCTM simulation including chemical reactions. The black line indicates the $20 \mathrm{dBZ}$ contour of computed radar reflectivity.

scenario, slightly underestimating column mass by approximately the same amount. Note that the pdfs are nearly identical to those from the first parameterization.

[31] The average hourly flash lengths of Théry et al. [2000] did not differentiate between IC and CG flashes. Dotzek et al. [2000] attempted to estimate typical flash lengths for IC and CG flashes separately on the basis of the heights of the main charge layers in the storm and the diameter of the storm with radar reflectivity greater than $30 \mathrm{dBZ}$. Using this method, they found typical lengths of $43 \mathrm{~km}$ for an IC flash, $26.5 \mathrm{~km}$ for a negative CG flash, and $29.5 \mathrm{~km}$ for a positive CG flash. It should be noted that because these estimates are based not on calculated lengths of IC and CG flashes, but on other parameters, there is a high degree of uncertainty. If these numbers are used in the model instead of the average hourly flash lengths from Théry et al. [2000], then a production scenario in which an IC flash produces $8.34 \times 10^{-3}$ moles NO per meter of flash channel length and a CG flash produces $1.35 \times 10^{-2}$ moles of NO per meter of flash channel length is needed to produce a favorable comparison with observations.

\subsection{CSCTM (With Chemistry) Results}

[32] To investigate the impact of chemistry on the concentrations of species of interest such as $\mathrm{NO}_{\mathrm{X}}$ and ozone, a CSCTM run including chemical reactions was performed. Profiles of $\mathrm{C}_{2} \mathrm{H}_{6}, \mathrm{C}_{2} \mathrm{H}_{4}, \mathrm{C}_{3} \mathrm{H}_{6}, \mathrm{C}_{3} \mathrm{H}_{8}, \mathrm{CH}_{3} \mathrm{OOH}, \mathrm{CO}, \mathrm{H}_{2} \mathrm{O}_{2}$, $\mathrm{HCHO}, \mathrm{HNO}_{3}$, isoprene, and PAN were taken from a July mean profile for the appropriate latitude and longitude of the EULINOX storm computed by the 3-D global University of Maryland Chemical Transport Model (UMD-CTM) [Park et al., 2004a] and are shown in Table 4. The NO to $\mathrm{NO}_{2}$ ratio at each CSCTM model level was based on the ratios from the UMD-CTM, but the initial $\mathrm{NO}_{\mathrm{x}}$ was equivalent to the values used in the passive version of the model. Profiles of hydrocarbons were scaled with the aid of airborne hydrocarbon measurements collected during the 1999 Konvektiver Transport von Spurengasen (KONVEX) campaign to ensure they represented values typical of the 


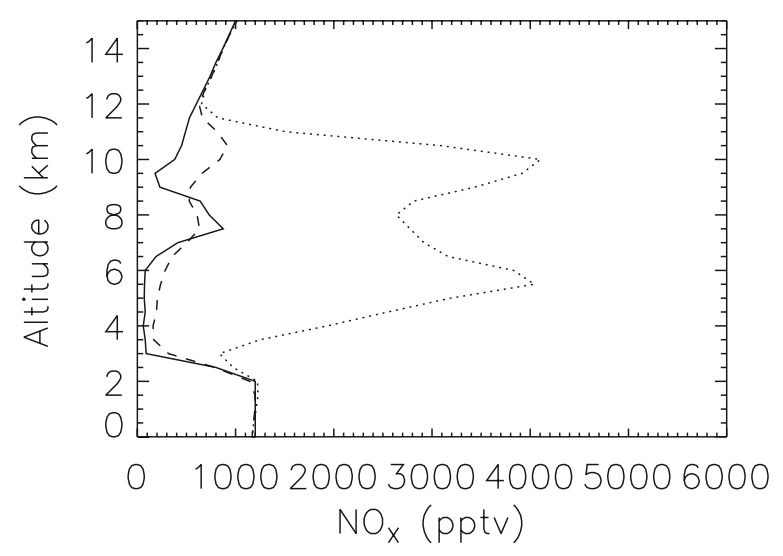

Figure 13. Mean $\mathrm{NO}_{\mathrm{x}}$ mixing ratios within the averaging box at the beginning of the passive model simulation (solid) and after $180 \mathrm{~min}$ with only transport simulated (dashed) and with lightning and transport simulated (dotted).

relatively polluted German atmosphere. Boundary layer concentrations of isoprene were held constant (e.g., at $1 \mathrm{ppbv}$ in the bottommost layer of the model) during daylight hours to reflect a balance between the emissions and reactive losses of these compounds. At the conclusion of the 180-min simulation, isoprene mixing ratios were approximately $6 \mathrm{pptv}$ in the core updraft region of the storm, and were typically less than 1 pptv in the anvil region. A 15-min "spin-up" simulation was performed using a column model which included the same chemical reactions as the full version of the 3-D CSCTM in order to allow the species to come into equilibrium. The CSCTM was run with the parameterization which uses observed flash rates as input assuming the lightning $\mathrm{NO}_{\mathrm{x}}$ production scenario $\mathrm{P}_{\mathrm{IC}}=\mathrm{P}_{\mathrm{CG}}=360$ moles NO/flash. Column mass and pdfs were computed from the model output using the same methods as for the passive version of the model. The use of global model output along with observed $\mathrm{NO}_{\mathrm{x}}$ results in a small decrease in $\mathrm{NO}_{\mathrm{x}}$ in the initial conditions during spin-up, such that the column mass for the flash rate and flash length scenarios simulated is $1.01 \times 10^{-3} \mathrm{~g} \mathrm{~N} \mathrm{~m}^{-2}$, a difference of $10.5 \%$ from the observations. A case in which no lightning $\mathrm{NO}_{\mathrm{x}}$ is included was also simulated to determine the lightning $\mathrm{NO}_{\mathrm{x}}$ effects on in-cloud chemistry.
[33] Figure 12b shows ozone concentrations $180 \mathrm{~min}$ into the simulation at the $9 \mathrm{~km}$ level. Lower ozone air has been transported upward in the convective cores and is present in the outflow of the storms. There is significant downward transport of ozone surrounding the cores of the cells, elevating ozone levels above those of the environmental air in the anvil region. At the conclusion of the $180 \mathrm{~min}$ simulation, lightning $\mathrm{NO}_{x}$ results in additional $\mathrm{O}_{3}$ production less than $0.1 \mathrm{ppbv}$ in regions outside of the cloud at $9 \mathrm{~km}$. At 8 and $9 \mathrm{~km}$, the inclusion of chemical reactions in the model continues to result in the underestimation of maximum ozone mixing ratios (see Figure 9), suggesting that downward transport may be underrepresented in the model.

[34] In order to identify the effect of lightning $\mathrm{NO}_{\mathrm{x}}$ on $\mathrm{O}_{3}$ production during the storm, $\mathrm{O}_{3}$ concentrations are averaged at $180 \mathrm{~min}$ in the simulation within the sampling box shown in Figure 12a at each model level for both the lightning and no-lightning cases. The values from the simulation without lightning $\mathrm{NO}_{\mathrm{x}}$ are subtracted from the values from the simulation which included a lightning $\mathrm{NO}_{\mathrm{x}}$ source. Figure 14 shows the average change in ozone due to lightning $\mathrm{NO}_{\mathrm{x}}$, as well as the maximum and minimum change at each level. During the lifetime of the storm, the injection of lightning $\mathrm{NO}_{\mathrm{x}}$ results in a net loss of ozone averaging less than $4 \mathrm{ppbv}$ at all levels. The maximum net loss during this 3 hour period exceeds 9 ppbv at $5.5 \mathrm{~km}$. This is due to the large quantities of $\mathrm{NO}_{\mathrm{x}}$ (up to $9 \mathrm{ppbv}$ ) being introduced into the model. Large NO mixing ratios from lightning rapidly destroy ozone through the $\mathrm{NO}+\mathrm{O}_{3}$ reaction as described by Wang and Prinn [2000]. The ozone destruction resulting from including lightning $\mathrm{NO}_{\mathrm{x}}$ in the model is likely short-lived. After the cloud dissipates, much of the $\mathrm{NO}_{2}$ produced by the $\mathrm{NO}+\mathrm{O}_{3}$ reaction will be photolyzed to produce $\mathrm{NO}$ and $\mathrm{O}\left({ }^{3} \mathrm{P}\right)$, resulting in $\mathrm{O}_{3}$ production (see following section).

\subsection{Chemistry-Only Model Results}

[35] The chemistry-only version of the CSCTM was used to estimate downstream ozone production in the 24 hours following the storm. Three-dimensional chemical fields at $180 \mathrm{~min}$ in the CSCTM simulation were used to initialize the chemistry-only version. For these calculations, the storm

Table 4. Initial Condition Profiles of Species Taken From the UMD-CTM and Included in the CSCTM

\begin{tabular}{|c|c|c|c|c|c|c|c|c|}
\hline Altitude, $\mathrm{km}$ & $\mathrm{C}_{2} \mathrm{H}_{6}, \mathrm{pptv}$ & $\mathrm{C}_{2} \mathrm{H}_{4}, \mathrm{pptv}$ & $\mathrm{C}_{3} \mathrm{H}_{6}, \mathrm{pptv}$ & $\mathrm{C}_{3} \mathrm{H}_{8}, \mathrm{pptv}$ & $\mathrm{HCHO}, \mathrm{pptv}$ & $\mathrm{HNO}_{3}$, pptv & $\mathrm{H}_{2} \mathrm{O}_{2}$, pptv & PAN, pptv \\
\hline 1 & 1260 & 140.0 & 200.0 & 298.0 & 1030.0 & 1800 & 1280 & 776 \\
\hline 2 & 820 & 32.9 & 60.7 & 114.0 & 452.0 & 593 & 1050 & 352 \\
\hline 3 & 718 & 15.9 & 38.9 & 71.4 & 308.0 & 323 & 845 & 366 \\
\hline 4 & 706 & 12.2 & 27.1 & 63.0 & 223.0 & 359 & 685 & 488 \\
\hline 5 & 716 & 11.3 & 25.5 & 65.7 & 175.0 & 314 & 612 & 587 \\
\hline 6 & 736 & 13.1 & 35.2 & 73.5 & 151.0 & 433 & 545 & 648 \\
\hline 7 & 756 & 15.9 & 50.2 & 81.9 & 136.0 & 530 & 469 & 675 \\
\hline 8 & 778 & 19.0 & 65.5 & 88.8 & 129.0 & 593 & 409 & 680 \\
\hline 9 & 804 & 22.2 & 75.8 & 95.4 & 132.0 & 641 & 403 & 670 \\
\hline 10 & 820 & 21.7 & 65.4 & 98.7 & 115.0 & 654 & 323 & 641 \\
\hline 11 & 830 & 17.8 & 45.6 & 98.4 & 88.1 & 649 & 229 & 606 \\
\hline 12 & 826 & 7.1 & 14.6 & 91.2 & 49.4 & 615 & 146 & 562 \\
\hline 13 & 856 & 3.8 & 4.3 & 96.0 & 36.5 & 647 & 119 & 531 \\
\hline 14 & 902 & 3.6 & 2.7 & 106.0 & 34.4 & 713 & 118 & 508 \\
\hline 15 & 958 & 4.6 & 4.1 & 119.0 & 36.8 & 838 & 134 & 501 \\
\hline
\end{tabular}




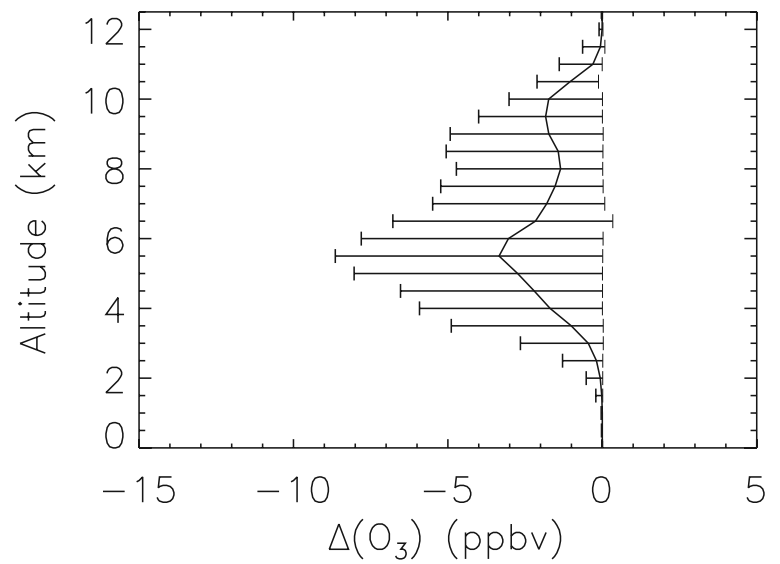

Figure 14. Change in $\mathrm{O}_{3}$ mixing ratios due to lightning $\mathrm{NO}_{\mathrm{x}}$ during the lifetime of the storm. Solid line is the average (over the sampling box), and brackets indicate minimum and maximum change.

is assumed to have dissipated and clear-sky photolysis rates are used. The same $24 \times 36 \mathrm{~km}$ sampling box shown in Figure $12 \mathrm{a}$ was used to analyze the results at the end of the 24 hour simulations. Table 5 gives the average mixing ratios within the sampling box at $9 \mathrm{~km}$ AGL for a number of species at the beginning and end of the chemistry-only simulation that included lightning $\mathrm{NO}_{\mathrm{x}}$. Ozone production averaged $1.5 \mathrm{ppbv}^{-1} \mathrm{day}^{-1}$ in the convective plume at this altitude, while substantial $\mathrm{NO}_{\mathrm{x}}$ conversion to $\mathrm{HNO}_{3}$ took place. Decreases in $\mathrm{HCHO}$ and $\mathrm{CH}_{3} \mathrm{OOH}$ were caused by photolysis.

[36] The impact of lightning $\mathrm{NO}_{\mathrm{x}}$ on ozone was examined by averaging the change in ozone mixing ratios within the box for the lightning and no-lightning cases. Figure 15 shows the change in net ozone production in the 24 hours following the storm due to lightning $\mathrm{NO}_{\mathrm{x}}$, calculated by subtracting the 24-hour change in $\mathrm{O}_{3}$ from the no-lightning simulation from the 24-hour change in $\mathrm{O}_{3}$ from the simulation with lightning $\mathrm{NO}_{\mathrm{x}}$. On average with lightning, there is additional net $\mathrm{O}_{3}$ production maximizing at approximately 5 ppbv day ${ }^{-1}$ at $5.5 \mathrm{~km}$. The injection of lightning $\mathrm{NO}_{\mathrm{x}}$ causes a decrease in net ozone production averaging less than 2 ppbv day ${ }^{-1}$ between 8 and $10.5 \mathrm{~km}$. There is a maximum decrease in net $\mathrm{O}_{3}$ production exceeding

Table 5. Average Species Concentrations at $9 \mathrm{~km}$ at the Beginning and End of the Chemistry-Only Simulation ${ }^{\text {a }}$

\begin{tabular}{lcc}
\hline \multicolumn{1}{c}{ Species } & $\begin{array}{c}\text { Average Mixing Ratio } \\
\text { Immediately Following } \\
\text { Convection, ppbv }\end{array}$ & $\begin{array}{c}\text { Average Mixing Ratio } \\
\text { 24 Hours After } \\
\text { Convection, ppbv }\end{array}$ \\
\hline $\mathrm{NO}_{x}$ & 3.28 & 2.11 \\
$\mathrm{O}_{3}$ & 87.6 & 89.1 \\
$\mathrm{HNO}_{3}$ & 0.334 & 1.25 \\
$\mathrm{HCHO}$ & 0.386 & $6.48 \times 10^{-2}$ \\
$\mathrm{H}_{2} \mathrm{O}_{2}$ & 0.524 & 0.339 \\
$\mathrm{CH}_{3} \mathrm{OOH}$ & 0.160 & $8.21 \times 10^{-2}$ \\
$\mathrm{CH}_{3} \mathrm{CO}_{3} \mathrm{NO}_{2}$ & 0.650 & 0.671 \\
$\mathrm{OH}$ & $1.57 \times 10^{-5}$ & $1.07 \times 10^{-5}$ \\
$\mathrm{HO}_{2}$ & $1.53 \times 10^{-4}$ & $2.80 \times 10^{-4}$ \\
$\mathrm{RO}_{2}$ & $4.57 \times 10^{-5}$ & $8.77 \times 10^{-5}$ \\
\hline
\end{tabular}

${ }^{a}$ Averages are computed over the sampling box shown in Figure 12a.

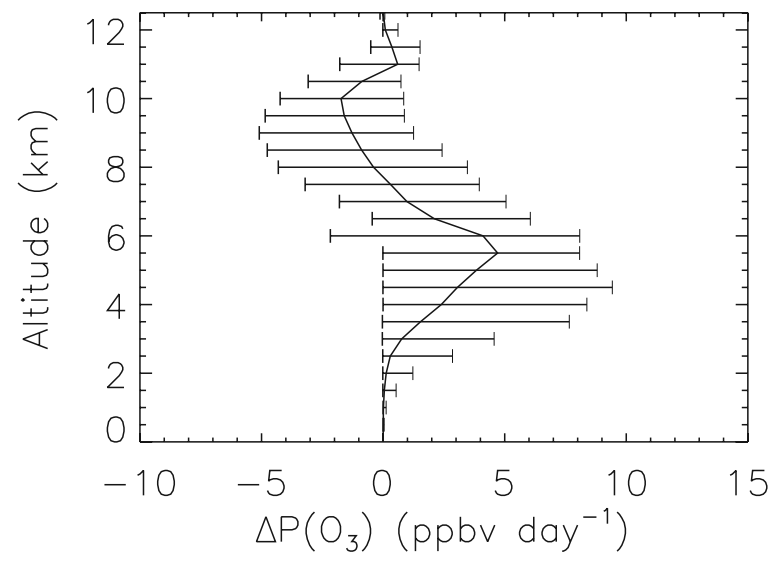

Figure 15. Change in net $\mathrm{O}_{3}$ production due to lightning $\mathrm{NO}_{\mathrm{x}}$ in the 24 hours following the storm. Solid line is the average (over the sampling box), and brackets indicate minimum and maximum change.

5 ppbv day ${ }^{-1}$ at $9 \mathrm{~km}$, and maximum additional net production of approximately 9 ppbv day ${ }^{-1}$ at $4.5 \mathrm{~km}$ due to lightning. Figure 16 shows a scatterplot of lightning $\mathrm{NO}_{\mathrm{x}}$ versus the 24-hour change in net $\mathrm{O}_{3}$ production resulting from the inclusion of lightning NO in the model for the grid cells contained in the sampling box at $9 \mathrm{~km}$. The general shape of the plot shows the change in net ozone production maximizing with lightning $\mathrm{NO}_{\mathrm{x}}$ mixing ratios less than 1 ppbv, then becoming less positive as lightning $\mathrm{NO}_{\mathrm{x}}$ increases. After lightning $\mathrm{NO}_{\mathrm{x}}$ mixing ratios exceed approximately 2 ppbv, lightning $\mathrm{NO}_{\mathrm{x}}$ causes decreased net ozone production in the model.

\section{Discussion}

[37] The estimated production per CG flash of 360 moles NO from the CSCTM for this storm is close to the value of 330 moles NO per flash from Fehr et al. [2004], with the difference due to the criteria for designating which BLIDS flashes were considered actual $\mathrm{CG}$ flashes in the two models. However, the assumed $\mathrm{P}_{\mathrm{IC}} / \mathrm{P}_{\mathrm{CG}}$ ratio of 1.4 yields

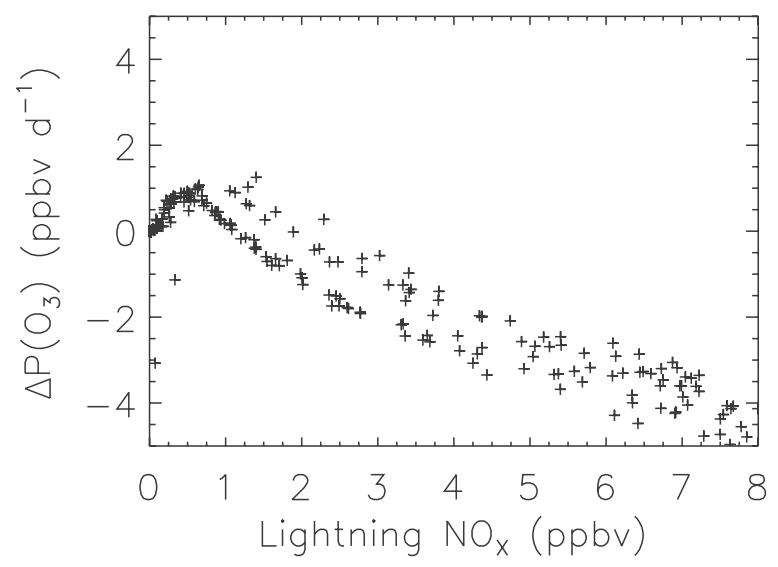

Figure 16. Change in net $\mathrm{O}_{3}$ production due to lightning $\mathrm{NO}_{\mathrm{x}}$ in the 24 hours following the storm versus lightning $\mathrm{NO}_{\mathrm{x}}$ at $9 \mathrm{~km}$ for grid cells contained in the sampling box. 
a production per IC flash of 462 moles NO which overestimates $\mathrm{NO}_{\mathrm{x}}$ when compared to the observed pdfs and column mass of observations. The production per CG flash of 360 moles NO is less than the production estimated for the 12 July STERAO storm by DeCaria et al. [2005] of 460 moles NO per CG flash. The IC production rate of 360 moles NO per flash is in the range of 345 to 460 moles NO per IC flash estimated by DeCaria et al. [2005] on the basis of calculated column mass and the average vertical $\mathrm{NO}_{\mathrm{x}}$ profile. Assuming a global average flash rate of 44 flashes $\mathrm{s}^{-1}$ [Christian et al., 2003], the lightning $\mathrm{NO}_{\mathrm{x}}$ production scenario from the EULINOX storm yields an annual global lightning $\mathrm{NO}_{\mathrm{x}}$ source of $7 \mathrm{Tg} \mathrm{N} \mathrm{yr}^{-1}$. Huntrieser et al. [2002] also estimated the global lightning $\mathrm{NO}_{\mathrm{x}}$ production rate in two ways. The first method involved calculating the average anvil $\mathrm{NO}_{\mathrm{x}}$ mixing ratios during EULINOX storms and multiplying by the average air flux out of the anvil and an estimate of the average number of thunderstorms occurring globally. The second method involved estimating NO production per meter flash channel length from NO spikes observed in the 21 July EULINOX storm and assuming a mean flash length and global flash rate. These methods yielded estimated global production rates of 3 and $4 \mathrm{Tg} \mathrm{N} \mathrm{yr}^{-1}$, respectively both of which are

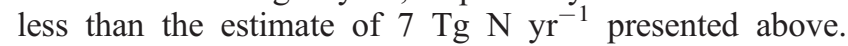
These differences could be because other EULINOX storms may have been less productive of lightning NO than the 21 July storm, or because the NO spikes analyzed from the 21 July storm may not have been representative of the lightning NO production in the storm. Our estimate of $1.25 \times 10^{-2}$ moles NO per meter flash channel length also compares favorably with other estimates of NO production per meter available in the literature. This estimate is within the range of $3.3 \times 10^{-4}$ and $1.7 \times 10^{-2}$ moles NO per meter flash channel length from Stith et al. [1999] on the basis of the 10 July STERAO storm. It is significantly larger than the value of $1.7 \times 10^{-3}$ moles NO per meter flash channel length estimated by Skamarock et al. [2003] which included a number of short-duration interferometer flashes not included in other studies of STERAO cases [e.g., DeCaria et al., 2005]. It is also larger than the estimate of $4.5 \times 10^{-3}$ moles NO per meter flash length obtained by Huntrieser et al. [2002].

[38] DeCaria et al. [2005] also examined the change in the net production of ozone resulting from lightning $\mathrm{NO}_{\mathrm{x}}$ in the convective plume following convection and found an average anvil net ozone production increase maximizing at $10 \mathrm{ppbv}$ day $^{-1}$ at $9 \mathrm{~km}$ AGL. Maximum increased ozone production at this level exceeded 12 ppbv day ${ }^{-1}$. The simulations presented of the 21 July EULINOX storm show on average smaller changes in net ozone production, maximizing at $5 \mathrm{ppbv} \mathrm{day}^{-1}$ at $5.5 \mathrm{~km} \mathrm{AGL}$. The maximum increase in the net production of ozone was greater than 9 ppbv day ${ }^{-1}$ at $4.5 \mathrm{~km}$. The EULINOX storm contained much larger $\mathrm{NO}_{\mathrm{x}}$ mixing ratios than the STERAO storm because of convective transport of boundary layer pollution as well as more lightning. Assuming a $\mathrm{P}_{\mathrm{IC}} / \mathrm{P}_{\mathrm{CG}}$ ratio of 1 for the STERAO storm yielded an average in-cloud $\mathrm{NO}_{\mathrm{x}}$ mixing ratio of only $0.9 \mathrm{ppbv}$ at $9 \mathrm{~km}$ AGL [DeCaria et al., 2005], while the average at $9 \mathrm{~km} \mathrm{AGL} 180 \mathrm{~min}$ into the simulation is $3.3 \mathrm{ppbv}$ in the EULINOX storm. As a result, $\mathrm{NO}_{x}$ was less efficient at $\mathrm{O}_{3}$ production in the EULINOX storm. The decrease in ozone production seen in the simulation of the EULINOX storm itself may be accentuated because of the changes to the lightning $\mathrm{NO}_{\mathrm{x}}$ parameterization which attempt to simulate individual lightning flashes and the spiky nature of $\mathrm{NO}_{\mathrm{x}}$ observations by placing NO from a flash into a small subset of randomly selected grid cells rather than uniformly distributing it over a larger area of the simulated cloud (as implemented by DeCaria et al. [2005]). The higher $\mathrm{NO}_{\mathrm{x}}$ mixing ratios cause a loss of ozone at some levels and only minimal amounts of production of ozone at others within the storm.

[39] Ozone production following convection has also been studied in global chemical transport models. Park et al. [2004b] used a global stretched grid chemical transport model (UMD-CTM) which included parameterized convection and lightning $\mathrm{NO}_{\mathrm{x}}$ production to examine the change in ozone following a convective event observed over Kansas and Oklahoma in 1985. When comparing ozone mixing ratios prior to convection with ozone mixing ratios in the day following convection, they found an enhancement in the downstream region at $9 \mathrm{~km}$ averaging $7 \mathrm{ppbv}$ and ranging from zero to $25 \mathrm{ppbv}$. Prior to convection, $\mathrm{O}_{3}$ at $9 \mathrm{~km}$ in the EULINOX simulation was $80.1 \mathrm{ppbv}$ and after the conclusion of the 24-hour chemistry-only simulation, $\mathrm{O}_{3}$ mixing ratios within the sampling box ranged from 80.9 to $97.2 \mathrm{ppbv}$ (an increase of $\sim 1$ to $17 \mathrm{ppbv}$ ) with an average of $89.1 \mathrm{ppbv}$, an increase of $9 \mathrm{ppbv}$. The range of the increase in $\mathrm{O}_{3}$ following convection calculated in the EULINOX simulation is less than the range of enhancement from Park et al. [2004b]. The average increase in $\mathrm{O}_{3}$ of 9 ppbv is slightly greater than the $7 \mathrm{ppbv}$ average from the Park et al. [2004b] study.

\section{Summary}

[40] The 3-D GCE cloud resolving model initialized with a single sounding was used to simulate a powerful thunderstorm observed on 21 July 1998 as part of the EULINOX field campaign. The model successfully reproduced a number of observed features of the storm including the splitting of the storm into two distinct cells, one of which developed supercell characteristics, and the other of which became multicellular. Time series of IC and CG flash rates were generated for both cells using BLIDS and interferometer data, and used in a parameterization of lightning NO production included in an offline 3-D CSCTM simulation driven by fields from the GCE simulation. This newly developed parameterization provides a means to better simulate the $\mathrm{NO}_{\mathrm{x}}$ resulting from lightning flashes in the highly electrified portion of a storm than is possible with the DeCaria et al. [2005] scheme.

[41] Probability distribution functions were calculated for $\mathrm{CO}_{2}, \mathrm{O}_{3}$, and $\mathrm{NO}_{\mathrm{x}}$ from aircraft observations taken during 7 penetrations of the storm and model output. A comparison of $\mathrm{CO}_{2}$ and $\mathrm{O}_{3}$ pdfs showed the model adequately represented the transport of tracer species. However, the lack of sufficient observations in the upper troposphere and lower stratosphere for use as initial conditions hampered a full evaluation of the model transport. Several lightning $\mathrm{NO}_{\mathrm{x}}$ production scenarios were simulated and the results were compared with observations to determine which was most appropriate for the storm. The scenario in which IC and CG 
flashes both produce 360 moles of NO per flash compared most favorably with observations, both in terms of pdfs and column mass. This production scenario for a strong supercell over Germany is equivalent to an annual global source of $7 \mathrm{Tg} \mathrm{N} \mathrm{yr}{ }^{-1}$. A second lightning $\mathrm{NO}_{\mathrm{x}}$ parameterization using average hourly flash lengths was employed to estimate a production per meter flash channel length of $1.25 \times$ $10^{-2}$ moles NO.

[42] Many modeling studies have assumed IC flashes are significantly less productive of $\mathrm{NO}$ than $\mathrm{CG}$ flashes because they are less energetic and pass through lower-pressure layers. Price et al. [1997] proposed that an IC flash typically produces $10 \%$ as much NO as a CG flash on the basis of estimates of energy dissipation. This has been disputed by Zhang et al. [2003] who estimate that IC flashes dissipate between 50 and $100 \%$ of the energy of CG flashes using recent observational evidence and a reanalysis of the assumptions made in the Price et al. [1997] study. Though a typical IC flash might be expected to produce somewhat less NO than a typical CG flash, the differences in pressure where the two types of flashes typically occur and in energy dissipation may be effectively countered by the fact that IC flashes can have greater lengths. Dotzek et al. [2000] estimated that the average length of an IC flash was greater than the average length of a CG flash in the 21 July EULINOX supercell on the basis of lightning and radar observations. Though IC and CG flashes on average may produce equivalent quantities of $\mathrm{NO}$, our results suggest that an IC flash may be less productive of NO per meter flash channel length than a CG flash.

[43] Assuming either the production scenario per flash or per meter flash channel length leads to a loss of ozone at all levels during the lifetime of the storm due to the resulting large NO mixing ratios. Chemical fields from $180 \mathrm{~min}$ in the CSCTM simulation were used to initialize a chemistryonly version of the model which includes diffusion but no further cloud-scale advection. The entire model domain is assumed to be translated downstream by the wind. This model was integrated forward 24 hours to estimate the effect of lightning $\mathrm{NO}_{\mathrm{x}}$ production on ozone in the day following the storm. Layer average increases in net production of ozone were found to maximize at $5 \mathrm{ppbv}$ day $^{-1}$ at $5.5 \mathrm{~km}$, though grid cells (particularly at 8 to $10.5 \mathrm{~km}$ ) with the highest concentration of lightning NO resulted in decreased net ozone production. We speculate that outflow from highly electrified storms or storms occurring over heavily polluted regions in other parts of the world (e.g., eastern U.S., east Asia, etc.) may also contain air parcels with reduced $\mathrm{O}_{3}$ production. Dilution of these convective plumes as they are advected farther downwind will result in a transition to increased $\mathrm{O}_{3}$ production. It appears that net $\mathrm{O}_{3}$ production over the first 24 hours in outflow from storms with large flash rates over polluted regions may be less than in the outflow from moderate flash rate storms over cleaner regions.

[44] Acknowledgments. This work was supported under National Science Foundation grants ATM9912336 and ATM0004120 and NASA grant NAG5-11276. We thank Wei-Kuo Tao of NASA GSFC for supplying the 3-D GCE model and Alex DeCaria of Millersville University for assistance with the CSCTM. We also thank Thorsten Fehr, formerly of DLR, for providing the initial condition sounding and for his assistance with lightning and radar data sets. The EULINOX project was funded by the European Commission (Research DG) through the Environment and Climate program (contract ENV4-CT97-0409). We thank the EULINOX team that carried out the airborne measurements (Schlager et al., DLR).

\section{References}

Bradshaw, J., D. Davis, G. Grodzinsky, S. Smyth, R. Newell, S. Sandholm, and S. Liu (2000), Observed distributions of nitrogen oxides in the remote free troposphere from the NASA global tropospheric experiment programs, Rev. Geophys., 38, 61-116.

Christian, H. J., et al. (2003), Global frequency and distribution of lightning as observed from space by the Optical Transient Detector, J. Geophys. Res., 108(D1), 4005, doi:10.1029/2002JD002347.

DeCaria, A. J., K. E. Pickering, G. L. Stenchikov, J. R. Scala, J. L. Stith, J. E. Dye, B. A. Ridley, and P. Laroche (2000), A cloud-scale model study of lightning-generated $\mathrm{NO}_{\mathrm{X}}$ in an individual thunderstorm during STERAO-A, J. Geophys. Res., 105, 11,601-11,616.

DeCaria, A. J., K. E. Pickering, G. L. Stenchikov, and L. E. Ott (2005), Lightning-generated $\mathrm{NO}_{\mathrm{X}}$ and its impact on tropospheric ozone production: A three-dimensional modeling study of a Stratosphere-Troposphere Experiment: Radiation, Aerosols, and Ozone (STERAO-A) thunderstorm, J. Geophys. Res., 110, D14303, doi:10.1029/2004JD005556.

Dotzek, N., H. Höller, and C. Théry (2000), VHF-interferometry and radar observation: Implications for nitrogen oxides production, in EULINOX-The European Lightning Nitrogen Oxides Experiment, edited by H. Höller and U. Schumann, Rep. DLR-FB 200028 , pp. $147-166$, Deutches Zentrum für Luft- und Raumfahrt, Köln, Germany.

Fehr, T., H. Höller, and H. Huntrieser (2004), Model study on production and transport of lightning-produced $\mathrm{NO}_{\mathrm{x}}$ in a EULINOX supercell storm, J. Geophys. Res., 109, D09102, doi:10.1029/2003JD003935.

Gallardo, L., and V. Cooray (1996), Could cloud-to-cloud discharges be as effective as cloud-to-ground discharges in producing $\mathrm{NO}_{\mathrm{X}}$ ?, Tellus, Ser. B., 48, 641-651.

Höller, H., and U. Schumann (Eds.) (2000), EULINOX-The European lightning nitrogen oxides project, Rep. DLR-FB 2000-28, 240 pp., Deutsches Zentrum fuer Luft- und Raumfahrt, Koln, Germany.

Höller, H., U. Finke, H. Huntrieser, M. Hagen, and C. Feigl (1999), Lightning-produced NOX (LINOX): Experimental design and case study results, J. Geophys. Res., 104, 13,911-13,922.

Höller, H., H. Huntrieser, C. Feigl, C. Théry, P. Laroche, U. Finke, and J. Seltmann (2000), The severe storms of 21 July 1998 - Evolution and implications for $\mathrm{NO}_{\mathrm{X}}$-production, in EULINOX - The European Lightning Nitrogen Oxides Experiment, edited by H. Höller and U. Schumann, Rep. DLR-FB 2000-28, pp. 109-128, Deutches Zentrum für Luft- und Raumfahrt, Köln, Germany.

Holmes, C., M. Brook, P. Krehbiel, and R. McRory (1971), On the power spectrum and mechanism of thunder, J. Geophys. Res., 76, 2106-2115.

Houze, R. A., Jr. (1993), Cloud Dynamics, 573 pp., Elsevier, New York.

Huntrieser, H., H. Schlager, C. Feigl, and H. Höller (1998), Transport and production of $\mathrm{NO}_{\mathrm{X}}$ in electrified thunderstorms: Survey of previous studies and new observations at mid-latitudes, J. Geophys. Res., 103, $28,247-28,264$.

Huntrieser, H., et al. (2002), Airborne measurements of $\mathrm{NO}_{\mathrm{x}}$, tracer species, and small particles during the European Lightning Nitrogen Oxides Experiment, J. Geophys. Res., 107(D11), 4113, doi:10.1029/ 2000JD000209.

Kessler, E. (1969), On the distribution and continuity of water substance in atmospheric circulations, Meteorol. Monogr., 10(32), 84 pp., Am. Meteorol. Soc., Boston, Mass.

Klemp, J. B., and R. B. Wilhelmson (1978), The simulation of threedimensional convective storm dynamics, J. Atmos. Sci., 35, 1070-1096.

Langford, A. O., R. W. Portmann, J. S. Daniel, H. L. Miller, and S. Solomon (2004), Spectroscopic measurements of $\mathrm{NO}_{2}$ in a Colorado thunderstorm: Determination of the mean production by cloud-to-ground lightning flashes, J. Geophys. Res., 109, D11304, doi:10.1029/2003JD004158.

Lin, Y.-L., R. D. Farley, and H. D. Orville (1983), Bulk parameterization of the snow field in a cloud model, J. Clim. Appl. Meteorol., 22, $1065-$ 1092.

Park, R. J., K. E. Pickering, D. J. Allen, G. L. Stenchikov, and M. S. Fox-Rabinovitz (2004a), Global simulation of tropospheric ozone using the University of Maryland Chemical Transport Model (UMD-CTM): 1. Model description and evaluation, J. Geophys. Res., 109, D09301, doi:10.1029/2003JD004266.

Park, R. J., K. E. Pickering, D. J. Allen, G. L. Stenchikov, and M. S. Fox-Rabinovitz (2004b), Global simulation of tropospheric ozone using the University of Maryland Chemical Transport Model (UMDCTM): 2. Regional transport and chemistry over the Central United States using a stretched grid, J. Geophys. Res., 109, D09303, doi:10.1029/2003JD004269. 
Pickering, K. E., Y. Wang, W.-K. Tao, C. Price, and J.-F. Müller (1998), Vertical distributions of lightning $\mathrm{NO}_{\mathrm{X}}$ for use in regional and global chemical transport models, J. Geophys. Res., 103, 31,203-31,216.

Price, C., and D. Rind (1992), A simple lightning parameterization for calculating global lightning distributions, J. Geophys. Res., 97, 99199933.

Price, C., and D. Rind (1993), What determines the cloud-to-ground fraction in thunderstorms?, Geophys. Res. Lett., 20, 463-466.

Price, C., J. Penner, and M. Prather (1997), $\mathrm{NO}_{\mathrm{X}}$ from lightning: 1. Global distribution based on lightning physics, J. Geophys. Res., 102, 5929 5941.

Ridley, B. A., K. E. Pickering, and J. E. Dye (2005), Comments of the parameterization of lightning-produced NO in global chemistry-transport models, Atmos. Environ., 39, 6184-6187.

Skamarock, W. C., J. E. Dye, E. Defer, M. C. Barth, J. L. Stith, B. A. Ridley, and K. Baumann (2003), Observational- and modeling-based budget of lightning-produced $\mathrm{NO}_{\mathrm{x}}$ in a continental thunderstorm, J. Geophys. Res., 108(D10), 4305, doi:10.1029/2002JD002163.

Stenchikov, G., K. Pickering, A. DeCaria, W. K. Tao, J. Scala, L. Ott, D. Bartels, and T. Matejka (2005), Simulation of the fine structure of the 12 July 1996 Stratosphere-Troposphere Experiment: Radiation, Aerosols and Ozone (STERAO-A) storm accounting for effects of terrain and interaction with mesoscale flow, J. Geophys. Res., 110, D14304, doi:10.1029/2004JD005582.

Stith, J., J. Dye, B. Ridley, P. Laroche, E. Defer, K. Baumann, G. Hübler, R. Zerr, and M. Venticinque (1999), NO signatures from lightning flashes, J. Geophys. Res., 104, 16,081-16,089.

Strahan, S. E., A. R. Douglass, J. E. Nielsen, and K. A. Boering (1998), The $\mathrm{CO}_{2}$ seasonal cycle as a tracer of transport, J. Geophys. Res., 103, $13,729-13,741$.

Tao, W.-K., and J. Simpson (1993), Goddard Cumulus Ensemble Model. Part I: Model description, Terr. Atmos. Oceanic Sci., 4, 35-72.
Tao, W.-K., et al. (2001), Microphysics, radiation and surface processes in the Goddard Cumulus Ensemble (GCE) Model, Meteorol. Atmos. Phys., $82,97-137$.

Théry, C. (2000), Evaluation of LPATS data using VHF interferomteric observations of lightning flashes during the EULINOX experiment, in EULINOX - The European Lightning Nitrogen Oxides Experiment, edited by H. Höller and U. Schumann, Rep. DLR-FB 2000-28, pp. 77-83, Deutches Zentrum für Luft- und Raumfahrt, Köln, Germany. Théry, C., P. Laroche, and P. Blanchet (2000), Lightning activity during EULINOX and estimations of $\mathrm{NO}_{X}$ production by flashes, in EULINOX - The European Lightning Nitrogen Oxides Experiment, edited by H. Höller and U. Schumann, Rep. DLR-FB 2000-28, pp. 129145, Deutches Zentrum für Luft- und Raumfahrt, Köln, Germany.

Wang, C., and R. G. Prinn (2000), On the roles of deep convective clouds in tropospheric chemistry, J. Geophys. Res., 105, 22,269-22,297.

Wang, Y., A. W. DeSilva, G. C. Goldenbaum, and R. R. Dickerson (1998), Nitric oxide production by simulated lightning: Dependence on current, energy, and pressure, J. Geophys. Res., 103, 19,149-19,159.

Zhang, X., J. H. Helsdon, and R. D. Farley (2003), Numerical modeling of lightning-produced $\mathrm{NO}_{\mathrm{x}}$ using an explicit lightning scheme: 1. Twodimensional simulation as a "proof of concept", J. Geophys. Res., 108(D18), 4579, doi:10.1029/2002JD003224.

H. Huntrieser and U. Schumann, Institut für Physik der Atmosphäre, Deutsches Zentrum für Luft- und Raumfahrt, Oberpfaffenhofen, D-82230 Wessling, Germany.

L. E. Ott and K. E. Pickering, Department of Atmospheric and Oceanic Science, University of Maryland, College Park, MD 20742, USA. (leo@atmos.umd.edu)

G. L. Stenchikov, Department of Environmental Sciences, Rutgers University, New Brunswick, NJ 08901-8551, USA. 